\title{
Bank lending strategy, credit scoring and financial crises
}

Citation for published version (APA):

Dinh, T. H. T., Kleimeier, S., \& Straetmans, S. T. M. (2013). Bank lending strategy, credit scoring and financial crises. Maastricht University, Graduate School of Business and Economics. GSBE Research Memoranda No. 053 https://doi.org/10.26481/umagsb.2013053

Document status and date:

Published: 01/01/2013

DOI:

10.26481/umagsb.2013053

Document Version:

Publisher's PDF, also known as Version of record

\section{Please check the document version of this publication:}

- A submitted manuscript is the version of the article upon submission and before peer-review. There can be important differences between the submitted version and the official published version of record.

People interested in the research are advised to contact the author for the final version of the publication, or visit the DOI to the publisher's website.

- The final author version and the galley proof are versions of the publication after peer review.

- The final published version features the final layout of the paper including the volume, issue and page numbers.

Link to publication

\footnotetext{
General rights rights.

- You may freely distribute the URL identifying the publication in the public portal. please follow below link for the End User Agreement:

www.umlib.nl/taverne-license

Take down policy

If you believe that this document breaches copyright please contact us at:

repository@maastrichtuniversity.nl

providing details and we will investigate your claim.
}

Copyright and moral rights for the publications made accessible in the public portal are retained by the authors and/or other copyright owners and it is a condition of accessing publications that users recognise and abide by the legal requirements associated with these

- Users may download and print one copy of any publication from the public portal for the purpose of private study or research.

- You may not further distribute the material or use it for any profit-making activity or commercial gain

If the publication is distributed under the terms of Article $25 \mathrm{fa}$ of the Dutch Copyright Act, indicated by the "Taverne" license above, 


\section{Maastricht University}

Thanh Thi Huyen Dinh, Stefanie Kleimeier, Stefan Straetmans

Bank Lending Strategy, Credit Scoring and Financial Crises

RM/ 13/053

\section{GSBE}

Maastricht University School of Business and Economics

Graduate School of Business and Economics

P.O Box 616

NL- 6200 MD Maastricht

The Netherlands 


\title{
Bank Lending Strategy, Credit Scoring and Financial Crises
}

\author{
Thanh Thi Huyen Dinh \\ Stefanie Kleimeier \\ Stefan Straetmans*
}

School of Business and Economics, Maastricht University, Tongersestraat 53, 6211 LM

Maastricht, The Netherlands

\begin{abstract}
Adverse selection inherent in the bank-borrower relationship typically intensifies during crises. This problem is especially severe in emerging markets, characterized by weak institutions and banks with poorly developed monitoring and screening abilities. Exploiting a unique sample of Vietnamese loans, we show that by updating their credit scoring models banks can significantly improve their screening abilities. Our results suggest that a crisis fundamentally changes default patterns and that a model based on post-crisis data outperforms models based on pre-crisis data. We conclude that updating credit scoring models is a viable alternative to credit rationing for banks and, in combination with relationship lending, can lead to improved loan pricing, efficiency and profitability.
\end{abstract}

Key words: credit scoring model, retail lending, crisis, emerging markets, adverse selection.

JEL codes: E44, G21, O16.

* Corresponding author, e-mail: s.straetmans@maastrichtuniversity.nl 


\section{Introduction}

Economic and financial crises are commonly accompanied by reductions in bank lending. During the financial crisis of 2007/08, banks substantially reduced credit to both domestic borrowers (Ivashina and Scharfstein, 2010) and international borrowers (Cetorelli and Goldberg, 2010 and 2012; Herrmann and Mihaljek, 2010; Milesi-Ferretti and Tille, 2010; Peek and Rosengren, 1997; Popov and Udell, 2012; Takats, 2010). ${ }^{1}$ According to Ivashina and Scharfstein (2010), new loans to large US borrowers fell by $47 \%$ during the peak of the financial crisis (fourth quarter of 2008) relative to the preceding quarter and by $79 \%$ relative to the peak of the credit boom (second quarter of 2007). The observed reduction in bank lending is driven by shifts in supply, e.g., credit rationing, as well as by shifts in demand (Bernanke and Gertler, 1995). While a reduction in loan demand can be attributed to the deterioration of economic conditions, i.e., fewer profitable investment opportunities for corporations or increased unemployment risk for consumers, the reduction of loan supply can be understood as the result of an increase in uncertainty and asymmetric information and an accompanying increase in adverse selection.

Lending is characterized by information asymmetry between banks and borrowers. Borrowers have an informational advantage over lenders because they know more than lenders do about the investment projects they wish to undertake. This informational advantage results in adverse selection and the classic "lemons" problem (Akerlof, 1970) that occurs because banks cannot differentiate "good" borrowers (low default risk) from "bad" ones (high default risk). Banks will therefore only make loans at interest rates reflecting average borrower quality, with high-quality borrowers paying an interest rate that is too high and lowquality borrowers paying an interest rate that is too low. Consequently, some high-quality borrowers may decide to drop out of the market. Adverse selection can also be described as a problem that occurs because potential bad borrowers are the ones that most actively seek loans which increases the chance that a loan might be made to a bad borrower. Stiglitz and Weiss (1981) analyze adverse selection and incentive effects in the loan market and show that a bank that raises its interest rate may suffer adverse selection because only risky borrowers will be willing to borrow at higher rates. Thus, banks might choose not to raise their interest rates to eliminate credit demand, resulting in possible credit rationing.

\footnotetext{
1 The collapse of corporate borrowing and lending should be distinguished from the liquidity crunch in shortterm interbank borrowing and lending during the 2007/2008 banking crisis. Although the causes are comparable, i.e., increased asymmetric information and adverse selection, this paper focuses rather on the collapse of corporate borrowing and lending.
} 
During an economic and financial crisis, the adverse selection problem typically intensifies on two fronts. First, the degree of information asymmetry increases as banks find it more difficult to distinguish good from bad borrowers. The behavior and performance of borrowers are expected to change significantly during a crisis, but banks have difficulties in correctly anticipating these changes and incorporating them into their credit decision making process (AD\&B, 2009). Second, increased default risk translates into a higher risk premium. These higher borrowing costs in turn cause more good borrowers to drop out of the market (Kirabaeva, 2011).

Banks have limited options to deal with adverse selection. On the one hand, they can ration credit. However, there are limits to how much banks can reduce credit supply in times of crises because a bank's business model and profitability still depend to an important extent on the size of its loan portfolio. In other words, they can also ration themselves into bankruptcy. On the other hand, banks can try to better control the adverse selection problem by incentivizing borrowers to behave well (e.g., by giving them "skin in the game" by requiring collateral) or by improving their ex ante screening of potential clients. Through such measures, banks rely mainly on "relationship" banking by having frequent contacts with their clients or using quantitative tools, such as credit scoring models (CSMs). However, CSMs are expected to quickly become unreliable when an economic and financial crisis strikes and when the economic environment, and thus borrowers' true default risk, deteriorates. For example, Jankowitsch et al. (2007) show that enhancing the statistical power of a rating system decreases the potential effects of adverse selection. We argue that re-estimating CSMs by using more recent data constitutes one way of improving the performance of rating systems such as CSMs.

Our study contributes to existing literature on the relationship between rating system performance and macro-economic performance; see, e.g., Avery et al. (2004), Bonfim (2009), Lucas and Klaassen (2006) or Carling et al. (2007). The existing literature claims that failure to consider general economic circumstances in a continuous way can diminish the performance of rating models. Our approach, however, is more specific in that we explicitly focus on the impact of financial crises on credit rating systems. To our knowledge, this approach is novel to the literature concerned with performance evaluation of dynamic credit rating systems such as CSMs. We estimate CSMs over different sample periods to show how a CSM's performance can be improved through re-estimation. More specifically, we hypothesize that updating a CSM using post-crisis data can improve the bank's screening 
ability and thus reduce adverse selection. ${ }^{2}$ We estimate a CSM for the Vietnamese retail banking market for the period around the 2007/2008 financial crisis. Our focus on Vietnam as an emerging country has two advantages. First, although developing markets were not directly affected by the crisis, they were nevertheless indirectly exposed through export and foreign investment channels. For example, credit grew in Vietnam between 2000 and 2011 at the substantial average annual rate of $31.45 \%$. However, the global crisis affected the Vietnamese banking market in 2008 , as credit growth dropped to approximately $20 \%$. Similarly, nonperforming loans rose to $3.5 \%$ in 2008 but in 2009 had dropped back to the 2007-level of approximately $2.0 \%$ (Quach, 2011). According to an IMF survey ${ }^{3}$, developing markets are now leading the global recovery out of the financial crisis, and Vietnam is among the emerging markets that have seen growth bounce back in 2011 . $^{4}$ Vietnam is thus a banking market in which crisis effects are clearly present, but short-lived. This allows us to investigate not only pre-crisis and crisis periods but also a distinct post-crisis period. Last but not least, the use of emerging market data enables us to evaluate the post-crisis performance of CSMs, which may provide useful insights for bankers, policy makers or regulators in the moredeveloped financial systems still faced with crises and unresolved structural problems. Second, we expect that the use of emerging market data produces value-added, as adverse selection is plausibly at least as severe - if not worse - in emerging markets as in developed markets, regardless of whether crisis periods are considered. This is because in developing markets information asymmetry can be substantial, due, e.g., to weak financial disclosure laws or the absence of credit bureaus. This problem is further aggravated by an underdeveloped banking system in which CSMs are not commonly used. The lack of government regulation and the weak institutional framework within which banks must operate makes the use of appropriate screening mechanisms, such as CSMs, relatively more important for emerging market banks than for banks in more developed banking systems.

Anticipating our results, we find (i) that estimated CSM parameters differ considerably for pre-crisis, crisis or post-crisis data and (ii) that updating CSMs using postcrisis data would help banks contain the increase in adverse selection problems occasioned by the crisis. In fact, post-crisis CSM can provide banks with several benefits. First, banks can

\footnotetext{
${ }^{2}$ Adverse selection also increases the likelihood of credit rationing in which some borrowers are arbitrarily denied loans. Consequently, profitable investment projects are not undertaken, which is bad for the economy as a whole and might prolong the effects of a crisis (Stiglitz and Weiss, 1981).

${ }^{3}$ See http://www.imf.org/external/pubs/ft/survey/so/2010/new120910a.htm for details.

${ }^{4}$ Developing East Asia, excluding China, is performing better with growth projected to be $5.6 \%$ in 2012, higher than the $4.4 \%$ recorded in 2011 . Vietnam's recovery from the global economic crisis has been rapid. The growth rates of key economic indicators, including real GDP, industrial production, investment, and exports, are expected to recover to near their pre-crisis trend growth rates.
} 
substantially improve profitability. Second, banks can reduce their adverse selection problems because they can price loans more accurately. Third, an updated CSM more effectively identifies good and bad loans and thus reduces the number of loans that must be reviewed in detail by the loan officer. Thus, banks can conduct their relationship lending more efficiently.

The remainder of the paper is structured as follows: Section 2 presents a general CSM as currently applied to retail credit and illustrates the modeling steps and decisions that must be taken in formulating a CSM. In section 3, credit scoring models are estimated using different samples of period-specific input data. Specific applications of different models regarding bank profitability, risk-based loan pricing, and relationship lending are explored in section 4 . Section 5 concludes.

\section{A credit scoring methodology for retail loans}

CSMs are commonly structured along the lines of Altman's (1968) Z-score model in which variables are selected based on their predictive power. ${ }^{5}$ Typically, a CSM is estimated using historical loan and borrower data to identify which borrower characteristics are most strongly associated with defaulted and non-defaulted loans. Based on a CSM estimated with historical data, a credit score can now be calculated for each new loan applicant, where a higher score indicates a better expected performance of the borrower and thus a lower probability of default (PD). This score must be compared with the CSM's cut-off rate to determine whether the loan application is accepted, rejected or requires further assessment. Thus, as part of the CSM developmental stage, calibration is also necessary so that an optimal cut-off rate, in line with the lender's objectives, can be determined.

The 2007/2008 financial crisis caused a fundamental change in the global economic environment. This change entails that existing assessment systems, including CSMs, based on historical pre-crisis data, are likely to have poor default-predicting power for post-crisis applicants. The crisis changed borrowers' payment behavior; therefore, adjustments will be required at all stages of CSM development, from variable selection to variable coding and from probability of default (PD) calibration to cut-off setting.

\footnotetext{
${ }^{5}$ For an overview of the bankruptcy prediction literature since Altman's original study, see Byström et al. (2005) or Philosophov and Philosophov (2002). The former paper is also the only one to investigate the issue for a developing country. See Laitinen (1999) for a discussion of the related literature on the prediction of credit risk ratings.
} 


\subsection{The estimation method}

The development of a CSM starts with a decision about the specification of the model, i.e., one must choose among decision trees, linear probability models, logit or probit regression models or multiple discriminant analyses. Following most of the existing literature, we opt for the logistic regression method. We start with a retail loan sample containing information on borrower characteristics and ex-post default status. A borrower's ex-ante PD is unobservable, but the logistic regression technique enables us to estimate it. This technique assumes the existence of a continuous latent variable $Z_{j}$ that is linear in the loan characteristics $\mathrm{x}$ of the bank's retail clients:

$\mathrm{Z}_{\mathrm{j}}=\mathrm{W}^{\prime} \mathrm{x}=\mathrm{w}_{1} \mathrm{x}_{\mathrm{j} 1}+\mathrm{w}_{2} \mathrm{x}_{\mathrm{j} 2}+\ldots+\mathrm{w}_{\mathrm{k}} \mathrm{x}_{\mathrm{jk}}+\varepsilon$

where $w_{k}$ is the coefficient of the $k^{\text {th }}$ variable $x_{j k}$ is the value of variable $k$ for applicant $j . Z_{j}$ is known as the $\mathrm{j}^{\text {th }}$ applicant's $\mathrm{Z}$-Score. $\mathrm{Z}_{\mathrm{j}}$ is ex-ante unobservable, and default can only be defined ex-post as a dummy variable (with default corresponding to a value of 1 and 0 otherwise). Equation (2) relates the default probability $\pi$ to the latent variable $Z$ by assuming that they are linked via a logistic distribution model. We estimate the parameters using iterative maximum likelihood estimation. Larger values of $\pi$ reflect a higher PD.

$\pi_{\mathrm{j}}=\frac{1}{1+\mathrm{e}^{-\left(\mathrm{W}^{\prime} \mathrm{x}\right)}}$

\subsection{Variable identification}

A choice must be made about which variables to initially consider for equations (1) and (2). There is no overall consensus regarding the number or types of initial variables to try. Some models start with as many as 50 variables. Table 1 presents a list of the more commonly used variables for retail CSMs. In CSMs for corporate loans, the variables are relatively similar across countries and are limited to financial statement data (Allen et al., 2004). For retail loans, direct measures of the financial strength of the borrower, such as income or the value of one's home, are included. Given the limited availability of such proxies for individuals, proxies that measure the financial strength of a borrower indirectly (e.g., education, household size, years at employer or postal code) must also be used. There appear to be only a few variables that are typical for developing countries, such as gender, religion, branch and loan officer. This finding can be explained by the fact that banks in most 
developed countries are prohibited by law from using variables such as gender, whereas banks in developing countries are not. Branch and loan officer variables can reflect branch policy, bonuses, experience or training levels. Their inclusion in the CSM for Bolivia might indicate that differences across branches and loan officers are more pronounced in less-developed banking markets. Except for these few variables, however, it appears that a retail CSM for a developing country can generally start with the same set of variables as a retail CSM for a developed country.

Note that not all variables are fully available. Values may be structurally missing (e.g., questions that are asked conditionally on the responses to previous questions). Alternatively, missing values might be due to a deficient information system in some branches or to customers who are unwilling to completely fill out application forms. Excluding all variables with missing values might substantially reduce sample size and lead to a loss of valuable information, whereas including variables with only a few valid observations might lead to unreliable results. To balance these two disadvantages, we first identify those variables that show a substantial number of missing values. Second, we rely on loan officers' expert knowledge and feeling for the data and borrower characteristics to identify which of these variables can or cannot be excluded from the model (Henley and Hand, 1997).

\section{[Insert Table 1 about here]}

\subsection{Variable categorization}

After the choice of the initial set of independent variables has been made, qualitative as well as quantitative variables must be coded. Coding of a quantitative variable is required when the relationship between the variable and default probability is nonlinear. As Thomas (2000) argues, instead of trying to map such a relationship as a straight line, borrowers can be grouped into various categories, thus generating a categorical variable. The latter approach is more commonly used in credit scoring, mainly because it can also be applied to qualitative variables. Thus, we adopt this approach for all our variables. To complete the coding of the variables, a value must be attached to each category. Boyle et al. (1992) show that variables can be coded based on the distribution of defaulted and non-defaulted loans in the sample. If a variable has $\mathrm{m}$ categories, let $\mathrm{g}_{\mathrm{i}}$ be the number of good (non-defaulted) loans belonging to the $i^{\text {th }}$ category and $b_{i}$ the number of bad (defaulted) loans belonging to the $i^{\text {th }}$ category. $G$ and $B$ are the total number of good and bad loans, respectively, in the whole sample, such that 
$G=\sum_{i=1}^{m} g_{i} \quad$ and $\quad B=\sum_{i=1}^{m} b_{i}$

Instead of using a simple coding rule ${ }^{6}$, estimates of the odd of good and bad loans in the $\mathrm{i}^{\text {th }}$ category are commonly used. We follow Crook and Shumway (1992) and code our variables as $^{7}$

$\ln \left(g_{i} / b_{i}\right)+\ln (B / G)$

For qualitative variables, for which the number of possible categories is very large, coding all categories becomes infeasible. For such cases, we follow Thomas (2000) and Boyle et al. (1992) recommendation and aggregate values of similar PD measured as $b_{i} /\left(g_{i}+b_{i}\right)$.

\subsection{Variable selection and estimation of the CSM}

Once the variables have been coded, equation (2) can be estimated. As is evident from retail CSMs in developed countries, the model can initially contain a large number of variables. While this might be statistically feasible for large samples, there are practical restrictions. Too many questions in an application form deter loan applicants, who may not answer all questions or decide to apply for a loan elsewhere. Efficiency and applicability thus require that the number of variables be reduced. We therefore apply a forward as well as a backward stepwise method that sequentially adds or withdraws variables to maximize the model's predictive accuracy (Henley and Hand, 1997). At this point, the final version of the CSM can be determined and the coefficients $\mathrm{w}_{\mathrm{j}}$ of equation (2) can be estimated.

\subsection{CSM's predictive accuracy}

The CSM should be tested for its predictive accuracy out-of-sample. The PD it produces is then compared to a cut-off value to establish whether a loan applicant will be a good (non-defaulting) or bad (defaulting) borrower. Initially, a cut-off value of $50 \%$ can be chosen so that an applicant whose estimated PD is greater (smaller) than $50 \%$ will be classified as a bad (good) borrower. This classification is then compared with the observed incidence of default to establish the accuracy of the model. A classification table, as shown in

\footnotetext{
${ }^{6}$ A simple rule assigns, for example, a value of 1 to the category with the lowest $\mathrm{PD}$, a value of 2 to the category with the second highest $P D$, etc.

${ }^{7}$ In each sub-sample, $\ln (\mathrm{B} / \mathrm{G})$ is constant. In practice, when banks are updating their CSM at regular intervals, this value will change with every update.
} 
Table 2 , is commonly employed at this stage. $G_{g}$ represents the number of correctly classified good loans, whereas $G_{b}$ represents the number of good loans that are incorrectly classified as bad loans. Similarly, $B_{b}$ represents the number of correctly classified bad loans, whereas $B_{g}$ represents the number of bad loans that are incorrectly classified as good loans. The percentage of correctly classified (PCC) loans serves as an accuracy measure. The percentage of correctly classified good loans $\left(\mathrm{PCC}_{\mathrm{good}}\right)$ is defined as the proportion of correctly classified good loans to the total number of observed good loans. Correspondingly, the percentage of correctly classified bad loans $\left(\mathrm{PCC}_{\mathrm{bad}}\right)$ is defined as the proportion of correctly classified bad loans to the total number of observed bad loans. Finally, the percentage of correctly classified total loans $\left(\mathrm{PCC}_{\text {total }}\right)$ is defined as the number of correctly classified loans relative to the total number of loans. Though simple to use, PCC may not always be an appropriate accuracy measure, as it implicitly assumes that the costs of misclassification of bad and good loans are equal. For banks, however, one classification error may be much more costly than another. To address this issue, Baesens et al. (2003) use two additional accuracy measures called sensitivity (SENS) and specificity (SPEC). In contrast to $\mathrm{PCC}_{\mathrm{bad}}$, which relates the predicted bad loans to the total number of observed bad loans, SPEC is defined as the ratio of the number of correctly classified bad loans to the total number of classified bad loans. Correspondingly, SENS is defined as the ratio of the number of correctly classified good loans to the total number of classified good loans. Banks may wish to minimize both $\mathrm{B}_{\mathrm{g}}$ and $\mathrm{G}_{b}$ simultaneously. However, reducing $\mathrm{B}_{\mathrm{g}}$ comes at the expense of increasing $\mathrm{G}_{b}$, and vice versa. Thus, banks should take into account differences in cost arising from misclassified good versus misclassified bad loans.

\section{[Insert Table 2 about here]}

One major drawback of the aforementioned assessment measures is that they depend on the selected cut-offs and default percentage of the sample. Therefore, these measures are not appropriate for comparing the performances of models constructed from different data sets. CSMs are therefore usually evaluated using a power curve such as the Cumulative Accuracy Profile (CAP) ${ }^{8}$ or the Receiver Operating Characteristic (ROC) curve (Kraznowski and Hand, 2009). Unlike the CAP curve and the aforementioned measures, a ROC curve

\footnotetext{
${ }^{8}$ The CAP curve depends on the composition of the portfolio (Basel Committee on Banking Supervision, 2005). Hence, the CAP curve cannot be used to monitor scoring models over time when the composition of the portfolio changes or to compare classifier performances of rating models across two different portfolios (Sobehart and Keenan, 2001).
} 
represents the CSM's performance for all possible cut-off values and is independent of the composition of the loan portfolio. A ROC curve is the most popular graphic representation of CSM performance. Therefore, in this paper, we focus on the ROC curve and its summary index, known as the Area Under the Curve (AUC), to compare the performance of our different models.

The ROC curve is represented by the non-diagonal plot of the true positive rate (SENS) on the vertical axis and the false positive rate (1-SPEC) on the horizontal axis, for all possible cut-off points. In Figure 1, a hypothetical ROC curve is plotted. A perfect model would correctly classify all defaults, and be represented by the horizontal line at the unit true positive rate. On the other side, a model with zero predictive power is represented by a 45 degree line. Any other model with some predictive power would be represented by a concave curve positioned between the two extreme cases.

\section{[Insert Figure 1 about here]}

In Figure 1, the area between the axis of the abscissa and the ROC curve (AUC) is a measure of discriminatory power. It takes values in the $[0.5,1]$ interval, where the two bounds correspond to models with zero and full discriminatory power, respectively. By normalizing the AUC index (AUC-0.5)/0.5=G, the Gini index G is obtained. This index, which can be considered as a general power statistic, is widely used in banking practice. The rule of thumb is that a CSM should be updated if $\mathrm{G}$ falls below approximately $20 \%$.

Neither AUC nor G depends on the proportion of defaulted loans in the bank's portfolio. Therefore, they can be used to monitor the performance of a CSM over time. However, similarly to measures such as PCC, SENS and SPEC, the main drawback of the ROC and AUC curves is the assumption of equal misclassification error costs. For most banks, the cost of $B_{g}$ will be much higher than the cost of $G_{b}$. In section 4.1 , we therefore introduce a more advanced method that explicitly takes these two costs into account.

\section{An application to the Vietnamese retail lending market}

From 1987 onward, Vietnamese economic reforms put the economy on a path from a centrally planned economy to a market economy. To date, however, Vietnamese banks have suffered from insufficient capital buffers, inadequate provisions for possible loan losses or defaults, low profitability and the slow pace of institutional reform. With respect to risk assessment and management, there are numerous difficulties, including a lack of transparency 
in non-performing loan disclosure. As part of a broader strategy, all banks have been asked by the State Bank of Vietnam (SBV) to develop a comprehensive "credit manual" that accounts for generally accepted international risk management practices and standards. The development of a proper CSM is an integral part of this initiative. By 2006, a number of large banks had implemented their CSM to meet the SBV's requirements.

Like many other open developing economies, Vietnam was affected by the 2007/2008 global financial crisis, which revealed structural weaknesses in Vietnam's economy. ${ }^{9}$ The direct impact on the Vietnamese economy remained small due to Vietnam's limited linkages with international financial markets and that more than $50 \%$ of the banking sector remains state-owned. Nonetheless, Vietnam was affected indirectly through trade FDI and financial capital movements. In addition, Vietnamese employment and economic growth were both negatively affected by the global financial crisis. According to reports from 41 of the 63 provinces and cities of Vietnam ${ }^{10}, 66,700$ workers (of a total 45 million) lost their jobs in 2008 , raising the national unemployment rate to $4.65 \%$. The situation deteriorated further in 2009 , with unemployment rising to $5 \%$ and economic growth slowing to a $6.5 \%$ annual rate. The rise in unemployment adversely affected domestic demand and consumer sentiment in Vietnam. In 2008, investment volumes slumped as investor concern about the long-term prospects of the Vietnamese economy grew. Credit growth declined to $20 \%$ compared with $54 \%$ in 2007 . The stock market experienced its worst performance since it was established. As a result, the government started easing monetary policy beginning in July 2008 by decreasing its benchmark interest rate six consecutive times.

Thus, like many other countries, Vietnam has experienced unprecedented and rapid changes resulting from the global financial crisis. Because lower economic growth and higher unemployment adversely affected loan performance, credit managers were obliged to reassess the accuracy of their credit assessment processes.

To better understand the potentially changing borrower credit risk faced by banks in developing countries affected by the global financial crisis, we estimate our credit scoring models based on the retail loan portfolio of a single privately owned Vietnamese commercial bank. We consider 66,226 retail loans signed between July 2006 and August 2010 and observe their performance, e.g., defaults versus non-defaults, through August 2011. The crisis

\footnotetext{
${ }^{9}$ An example is the low efficiency of investment, especially public investment. The incremental capital output ratio (ICOR) is significantly higher in Vietnam than in other Asian countries, suggesting the lower efficiency of capital usage in Vietnam.

${ }^{10}$ There are large differences in the reported Vietnamese unemployment rate, depending on the data source. We use the unemployment data announced by the Vietnamese labor and employment ministry.
} 
affected Vietnam's banking market only in 2008, and our bank is representative of the Vietnamese banking market in terms of loan volume. Figure 2 shows the monthly number of new loans supplied by our bank from 2006 to 2010. The number of loans rose steadily and steeply in 2006 and 2007 and reached a maximum of more than 3,000 new loans in January 2008. During 2008, however, the number of new loans dropped sharply to almost zero in August 2008. Since then, the number of new loans has steadily increased again and by late 2010 had almost reached pre-crisis levels. Motivated by these observations, we split the bank's loan portfolio into the following sub-samples: a pre-crisis sample, which contains 25,302 loans signed between July 2006 and February 2008; a crisis sample, which includes 7,432 loans signed between March 2008 and December 2008; and a post-crisis sample, which includes 18,704 loans signed between January 2009 and December 2009. Finally, our holdout sample contains 14,788 loans signed, following the post-crisis period, between January 2010 and August 2010. We estimate four models based on different combinations of the three samples. Model 1 uses the full-period sample, combining pre-crisis, crisis and post crisis samples. Model 2 covers periods of stability, combining the pre-crisis and post-crisis samples. Model 3 uses the pre-crisis sample. Finally, model 4 uses the post-crisis sample. We then assess the performance of these different models based on the post-crisis hold-out sample. In this way, we put ourselves in the position of a loan officer required to assess the unknown exante creditworthiness of a loan applicant in 2011. The accuracy of a model can be evaluated by comparing its predictions with ex-post observed credit risks.

[Insert Figure 2 about here]

\subsection{Variable identification}

As Panel A of Table 3 shows, the bank distinguishes four borrower groups based on loan purpose: borrowers raising money to finance their business (conmercial); borrowers raising money for living expenses or consumption (consumer); borrowers raising money for the purchase or maintenance of a home (real estate); and borrowers raising money via the bank's credit card facility or the bank's employees borrowing money for unknown purposes (other). Thus, our sample includes both consumer and business loans. In Vietnam in general and in our bank in particular, business loans typically finance relatively small private businesses. Due to a lack of reliable up-to-date financial data on these corporate borrowers and to the boundary between the private and business property of an entrepreneur often being vague, the bank assesses these loans based on the personal information of the entrepreneur. 
Real estate and consumer loans are the most frequent loans, accounting for $37 \%$ and $26 \%$ of the bank's loan portfolio, respectively. The remaining loan types account for only $16 \%$ to $20 \%$ of the bank's loan portfolio. Over the pre-crisis sample, the bank appears to grant more loans for commercial and unknown purposes than for consumer purposes: the bank grants $24 \%$ of its loans for unknown purposes, $21 \%$ for business purposes and only $14 \%$ for consumer purposes. In terms of loan size, loans granted post-crisis are much larger than loans granted pre-crisis. This can be partly explained by the high inflation rates in Vietnam, which usually run at $7-9 \%$ annually but sharply increased in 2008 to $23.1 \%$. It is also possible that since the crisis, the bank has focused on larger loans for more-effective scanning and monitoring. However, the variations in loan size between the crisis and pre-crisis samples are substantially smaller than in the post-crisis samples. Thus, the pre-crisis and crisis loans are more homogeneous with respect to size than the post-crisis loans.

As Figure 2 shows, our bank's loan portfolio represents the development of the overall Vietnamese banking market very well. The crisis is reflected in a sharp but short-lived reduction in lending, as the number of loans in our sample drops from 25,302 in the pre-crisis period to 7,432 in the crisis period. Thus, in terms of loan volume, e.g., credit rationing, the bank appears to have recovered rapidly. The bank considers 90 days of payment delay, or at least three consecutive payment delays, as loan default. Defaulted loans account for $3.8 \%$ of the 66,226 loans in our sample, which is slightly lower than the $4.9 \%$ of defaulted loans in the bank's total loan portfolio. ${ }^{11}$ Over time, default rates vary, ranging from as little as $2.6 \%$ for post-crisis loans to $5.1 \%$ for pre-crisis loans. The low default rate for post-crisis loans may be attributable to the bank reserving loans for its best customers at this stage and to the fact that the most severe impact of the financial crisis was over before these loans were signed. The high default rate on loans signed before the crisis is understandable, as these loans suffered during the crisis period. Comparing defaulted and non-defaulted loans of different subsamples (cf. Panel B of Table 3) reveals additional differences. For all samples, the defaulted borrowers are younger, have been bank customers for shorter periods of time, have fewer savings accounts at the bank and have less collateral. In contrast to the other samples, in the post-crisis sample, the defaulted borrowers have higher incomes, more past loans and more current accounts. It appears that after the crisis, the bank has given priority to high-income

\footnotetext{
${ }^{11}$ The population PD of $4.9 \%$ is in line with the PD reported on banks' financial statements but is far below the alternative figures of $35 \%$ to $70 \%$ reported by the World Bank. For the purposes of this study, we assume that the data provided to us by the bank are an accurate record of all defaults. As long as any potential misreporting is not structurally related to borrower characteristics (i.e., the variables included in our CSM), this assumption is acceptable, as it does not affect the estimation of the model but would lead only to an overstatement of the predictive accuracy of the model.
} 
repeat borrowers. When discussing the coding of variables in section 3.2, we will investigate in greater detail the relationship between borrower characteristics and default probability.

[Insert Table 3 about here]

\subsection{Variable coding, selection and model estimation}

We can only estimate a CSM when the loan applicant provides the relevant information at the time of loan application. Currently, the bank records more than 30 variables pertaining to loan and borrower characteristics. The bank, however, grants a loan even if the applicant does not provide full information. More specifically, less than $10 \%$ of borrowers provide complete information at the time of application. The difference between sample versus population $P D$ thus implies that a borrower who sufficiently fills in the loan application form has a lower PD than someone who does not properly complete the form. This is also consistent with one of the strategies used in practice to cope with missing values, as noted by Henley (1995): "a refusal to answer a particular question may be indicative of greater risk". Additionally, we eliminate certain variables from our CSM that almost exclusively take one value. For instance, the field 'Home phone (yes/no)' is filled with "yes" by more than $99 \%$ of borrowers. To obtain a sufficiently large sample of loans with complete and meaningful information, we rely on the expert knowledge of the loan officer and identify 17 relevant variables with relatively few missing values, as listed in Table $4 .{ }^{12}$ Our sample of 66,226 loans is thus based on 17 variables, and the criteria for selecting them are based on expert knowledge.

For each variable, borrowers are first grouped into categories. Categories can differ by sample. In preliminary analyses we found that the impact of our quantitative variables on default probability is rather similar in all samples except in the post-crisis sample. Thus, we use the same categories in models 1 to 3 but create slightly different categories for model 4 . The categories of models 1,2 and 3 are shown in Table 4, together with the default rates estimated for each category using the total data set, which is equivalent to the data set used for model 1. Categories and their default rates in model 4 are shown in Table A-1 of the

\footnotetext{
${ }^{12}$ We exclude the following characteristics: credit line, living expenses, frequency of principal payment, frequency of interest payment, outstanding balance in saving account, outstanding balance in debit account, subincome and number of days in arrears, relations with other banks, number of dependents, home phone, mobile phone, age of partner and occupation of partner.
} 
Appendix. The values of the categories are then estimated using equation (4). These values differ by model, as the numbers of bad and good loans in each category differ by data set. ${ }^{13}$

[Insert Table 4 about here]

For each model, after the variables are coded the forward stepwise method is used to select among these 17 initial variables. This method starts with a model without any independent variables and sequentially adds variables. At each step, the variable that leads to the greatest improvement in predictive accuracy - in terms of the highest score statistic conditional upon a significance level of less than $10 \%$ - is added. The process continues until no variable with a significance level of less than $10 \%$ remains. Based on the forward stepwise method, a subset of the initial 17 variables is included in the CSM. To ensure that the selected variables are the most powerful predictors, the backward stepwise method is applied as well. Here, the starting point is a model that contains all 17 initial variables. At each step, the method eliminates the weakest variable so that only the strongest predictors are retained in the final CSM. As expected, the backward stepwise method selects the same number of variables as the forward stepwise method. The remaining variables are excluded for one of two reasons: first, because they have insignificant coefficients and do not contribute to the explanation of the dependent variable's variance; second, because they are correlated with included variables. Together with adding the most predictive variables to the model, at each step of the backward stepwise regression, the tolerance (1-Ri2) of every excluded variable is calculated. Those variables with tolerances of less than $80 \%$ (i.e., with $20 \%$ or more of the variance of the variable explained by variations in the other variables) are considered for deletion. In the case of multicollinearity, the inclusion of all variables leads to inferior results in the hold-out sample.

As observed in Table 5, models 1 to 4 have 13,11, 12, and 10 selected variables, respectively. The four models have substantial overlap in the variables selected. Fifteen variables are selected in at least one of the four models. Variables pertaining to the bankborrower relationship (Time with bank, Number of prior loans) become more important during the post-crisis period, whereas borrower characteristics such as income, education, occupation and residential status become less important. Income appears only in model 3,

\footnotetext{
${ }^{13}$ In line with our general discussion in section 2.2, we find that most of our variables are not unique to Vietnam in particular or even to developing countries in general. However, when categorizing and coding the variables, we take the specific circumstances in Vietnam into account. See Appendix B for details.
} 
which uses the pre-crisis sample only. Five of the 12 predictors in Crook et al. (1992) CSM for the UK, as shown in Table 1, are incorporated into our CSM: Time with bank, Number of saving accounts, Region, Residential status, and Number of current accounts. Crook's longer list of the 24 most typical variables overlaps with eight of our variables. Thus, our CSMs reflect - to some extent - the international norm of credit scoring. Such variables as Loan duration or Gender, however, are unique to developing country credit scoring and are indeed very effective predictors in our CSMs. First, Gender might be truly indicative of default or might simply reflect underlying risks. For Vietnam, we conclude that gender helps in the proper assessment of credit risk, even when other risk factors such as loan purpose or collateral value are taken into account. As shown in Table 4, women have a lower probability of default than men. Consequently Gender is significant and selected in all 4 models. Goetz and Gupta (1996) also find that women in Bangladesh have higher repayment rates than men due to their meaningful control over their investment activities. Furthermore, Gender might also be indicative of income, a fact that may explain the absence of more-traditional income proxies (Income, Occupation or Time at current employer) from most of our models. Second, Loan duration, as a measure of the borrower's intentions, risk aversion, or self-assessment of repayment ability, is unique to the Vietnamese context, which indicates that Vietnamese banks cannot rely solely on their own assessment of the borrower but must also rely on the borrower herself, who appears to honestly and accurately state her own loan capacity. In this context, Time with bank and Number of prior loans, as the first and third most important predictors, reflect the borrower's relationship with the bank and, thus, the role such relationships play in the Vietnamese loan market. The first indication of crisis effects on the CSM is observed in differences between the variables selected pre- and post-crisis and in the switching of certain variables' importance rankings. For example, post-crisis personal information appears to lose importance and is no longer predictive, whereas such variables as Time with bank and Number of prior loans ${ }^{14}$ become more predictive of default. These characteristics of the bank-borrower relationship represent soft information (repayment incentives and behavior, for instance) that cannot be observed directly. With fundamental economic changes triggered by the crisis, the value of hard information, e.g., borrower characteristics, diminishes, but the value of soft information persists. However, to properly assess the accuracy of these CSMs, they should be applied out-of-sample.

\footnotetext{
${ }^{14}$ Similarly, Vogelgesang (2003) finds that frequent borrowers face higher repayment problems during economic crises.
} 


\subsection{Model calibration and out-of-sample assessment}

Table 6 shows AUC and Gini measures in-sample and out-of-sample for our four estimated models, and ROC curves are shown in Figure 3. The in-sample performance measures of the four models are very close, whereas the hold-out sample measures are quite distinct. Because we are most interested in the performance of these models with respect to the hold-out sample, we now focus on the hold-out sample performance measures. Model 3, estimated using the pre-crisis sample, performs worst, with a Gini coefficient of $12 \%$ and an AUC of $56 \%$. In contrast, model 4 , estimated using the post-crisis sample, performs best, with a Gini coefficient of $26.22 \%$ and an AUC of $63.11 \%$. Models 1 and 2 perform at intermediate levels between the other two. This preliminarily assessment indicates that the borrower population has changed over time and that the CSM constructed based on pre-crisis data is out of date following the crisis. This result answers the banks' question of whether to reformulate their CSMs following the crisis: Yes, they should adjust their CSMs, if not redevelop them entirely. Additionally, banks in general do not want to waste any data and, hence, may want to include loans signed before and during the crisis in their updated CSMs. They should, however, consider this step very carefully, as it could significantly reduce the performance of their new model, as we show in the cases of models 1 and 2. To emphasize the improvement in the performance of model 4 , we continue to look more closely into the calibration of this model compared with those of the others, particularly model 3.

\section{[Insert Table 6 and Figure 3 about here]}

When the out-of sample is used to calibrate models 3 and 4, we find, as expected, a significant difference in the predicted PDs between observed defaulted and observed nondefaulted borrowers. Table 7 shows that for model 3, the average of predicted PDs is $2.53 \%$ for non-defaulted loans compared with $7.25 \%$ for defaulted loans. However, the ranges of predicted probabilities are rather large and overlap for the two loan groups. For defaulted loans, the PDs range from $0.34 \%$ to $31.53 \%$ compared with $0.03 \%$ to $21.82 \%$ for nondefaulted loans. The results are slightly better for model 4 , where the average of the predicted PDs is $2.37 \%$ for non-defaulted loans and $8.24 \%$ for defaulted loans. Defaulted loans, under model 4, have PDs that range from $0.40 \%$ to $24.69 \%$ whereas non-defaulted loans have PDs that range from $0.00 \%$ to $23.37 \%$. Table 7 also reports the observed versus predicted PDs for 
different loan groups, generated by sorting all loans of similar predicted PDs into five groups of approximately equal size. The average estimated PD of model 3 is $2.66 \%$, compared with an observed PD of $2.58 \%$, whereas the average estimated PD of model 4 is 2.95 . Thus, model 4 overestimates default probabilities more often than model 3 . However, if we more closely examine the different loan groups, we see that model 4 is better at distinguishing between the lowest and highest risk groups from the remaining groups, as shown by the larger gap between their observed PDs. A more detailed accuracy analysis using the PCC, SENS and SPEC indicators is thus warranted.

[Insert Table 7 about here]

The determination of the optimal cut-off point for a CSM depends on the preferences of the bank. Our bank - though it does not have a CSM in place, relying instead on subjective credit assessment - has set a target for non-performing loans. Assuming this target is $1.5 \%$, we must set the cut-off point to achieve a SENS of $98.50 \%$ (SENS $=100 \%-1.5 \%=98.50 \%$ ). At first glance, one might think that to achieve this target, banks should accept only customers who have predicted PDs of less than $1.5 \%$. A cut-off of $1.5 \%$ would, however, lead to a SENS higher than $98.50 \%$ and, thus, a lower expected PD. Panels A and B of Table 8 show that a cut-off of $5.3 \%$ would achieve the desired result for model 3, and a cut-off of $7.4 \%$ would do the same for model 4. Comparing the accuracy of these cut-offs in the two models reveals the following dynamics: assuming tolerance of a small number of bad loans (a decrease in PCC $_{\text {bad }}$ from $49.97 \%$ to $45.81 \%$ ), model 4 increases its number of correctly accepted good loans substantially compared with model 3 (a rise in $\mathrm{PCC}_{\text {good }}$ from $86.92 \%$ to $94.58 \%$ ). Hence, following the crisis, when credit managers would tend to be prudent in their loan approvals, a more accurate model, such as model 4 , will achieve greater certainty regarding good and bad loans in the bank's portfolio. Credit managers could now be more confident that a large number of good loans can compensate for a small number of bad loans and that profit can thus be maximized. In terms of SENS and SPEC, both models have a SENS of $98.50 \%$, while the SPEC for model 3 is $9.2 \%$ and that for model 4 is $18.3 \%$. Our SENS accuracy is slightly higher than that reported in other studies, while our SPEC accuracy is average or slightly below average. For example, Baesens et al. (2003) survey reports SENS measures up to $96.36 \%$, whereas some models of UK data have a SPEC of $0 \%$. SENS and SPEC, however, depend on the default percentage of the sample, so any comparison of these can be misleading unless the models are applied to the same data as our models. Compared with model 3, model 
4 can improve SPEC by $9.1 \%$ at no cost to SENS. Nevertheless, to conclude that model 4 can indeed improve the bank's economic performance, the costs of different error types must be taken into account.

\section{[Insert Table 8 about here]}

\section{Credit scoring and bank strategy}

In the previous section, cut-off values of $5.3 \%$ and $7.4 \%$ were chosen for the bank to achieve its assumed default target of $1.5 \%$ under models 3 and 4, respectively. However, is this optimal when the bank follows other strategies such as minimizing the time spent on credit assessment or maximizing returns? To answer this question, we examine alternative ways to set the cut-off points for the CSM.

\subsection{Profitability}

A CSM's benefit may lie in the positive effect a new credit assessment policy has on the bank's profitability, which is especially important following a crisis. If an updated CSM leads to increased bank profits, then the loan officer has a clear incentive to increase loan approvals following periods of depressed loan supply. Schreiner (2003) suggests measuring changes in profits in terms of opportunity cost. In particular, he focuses on the ratio of good loans lost $\left(G_{b}\right)$ to bad loans avoided $\left(B_{b}\right)$.

$\Delta$ profit $=$ cost per bad loan $* B_{b}$ - benefit per good loan $* G_{b}$

Given the selected cut-offs, as shown in Panels A and B in Table 8, a comparison between models 3 and 4 shows that model 3 avoids 15 additional bad loans (190 minus 175) by foregoing 1,104 good loans $(13,625$ minus 12,521). Thus, the tradeoff factor in model 3 is quite high: it foregoes 73.6 good loans for each bad loan avoided. To assess changes in profits, we assume a relationship between the cost per bad loan and the benefit per good loan. Because data for developing countries are not available, we use data from the credit card market in industrialized countries as a benchmark. In industrialized countries, practitioners maintain that at least 10 good loans are required to cover the cost of one bad loan (Schreiner 2003). Under this assumption, a cut-off of $7.4 \%$ for model 4 leads to an increase in profits of 26.12 billion VND (approximately $€ 1,279,080$ ), whereas a cut-off of $5.3 \%$ for model 3 leads to an increase in profits of only 0.40 billion VND (approximately $€ 19,800$ ), which would 
indicate that our bank should prefer model 4. Figure 4 shows how this change in profits varies for different cut-off points of the two models. In particular, it reveals that neither a cut-off of $5.3 \%$ for model 3 nor a cut-off of $7.4 \%$ for model 4 maximizes profits. Instead, maximum profits are obtained by model 4 at a cut-off of $9.1 \%$. This results in an expected PD of $1.62 \%$, which is slightly above target and implies that our bank has set a rather too conservative strategy. A further look at Figure 4 reveals that at all cut-off values model 4 always outperforms model 3 in terms of profit-maximization. A cut-off of $9.1 \%$ also maximizes profit if model 3 is used. However, this maximum profit is less than that achieved with model 4 . The optimal cut-off point for model 3, moreover, results in an expected PD of $1.84 \%$, which exceeds $1.62 \%$, the expected PD if the optimal cut-off is used for model 4 . In summary, because model 4 , which is based on post-crisis data, always leads to superior profits compared with model 3 , we conclude that an updated CSM does indeed provide a bank with an incentive to lend.

\section{[Insert Figure 4 about here]}

\subsection{Efficiency in transactional versus relationship lending}

Should banks rely exclusively on their CSM, i.e., transactional lending, or should there also be room for relationship lending? The benefits of transactional lending, e.g., credit scoring, are clear. Mester (1997), for example, reports that credit scoring has substantially reduced the length of the loan approval process, from two weeks to 12.5 hours for smallbusiness loans in the US and from nine to three days for consumer loans in Canada. Once a CSM is in place, these benefits can be achieved at a cost of $\$ 1.50$ to $\$ 10$ per loan. Mester (1997) also reports that Banc One exclusively uses credit scores for loans of up to $\$ 35,000$ and approves a further $30 \%$ of all loans below $\$ 1$ million based solely on credit scores. The downside, however, can be substantial. Schreiner (2003) recalls the case of a Bolivian finance company that relied exclusively on its CSM and went bankrupt. The recent contraction in small business lending in the United State, where the use of CSMs is most advanced, has also cast doubt on transactional lending, which relies exclusively on CSMs. ${ }^{15}$ Through their relationships with borrowers, banks can discover qualitative risks that are not quantifiable in terms of "hard" variables. Thus, a combination of transactional and relationship lending can be valuable. Rio et al. (2011) suggest that transactional lenders use CSM primarily for cost-

\footnotetext{
${ }^{15}$ See, for instance, "When Business Credit Scores Get Murky", Wall Street Journal, March 18, 2010.
} 
saving purposes, whereas relationship lenders combine CSM with relationship lending to reduce the asymmetric information banks face with respect to potential borrowers. During the $2007 / 08$ crisis, transactional lenders suffered higher default rates on loans approved exclusively on the basis of borrower's credit scores, e.g., using CSMs. ${ }^{16}$ In contrast, relationship lenders suffered lower default rates on those loans approved based on borrowers' soft information in combination with credit scores. Thus, a combination of relationship, softinformation-based lending and transactional, CSM-based lending might be especially valuable during and after periods of crisis when a borrower's condition, and thus the determinants of default probability, undergo fundamental change.

To implement such a strategy in our CSM, we rely on Mester (1997), who reports that US banks have credit officers review their CSMs' decisions, particularly for loan applicants with scores close to the cut-off point. For the First National Bank of Chicago, this led to substantial changes in credit decisions regarding small-business loans. Approximately $25 \%$ of the applications rejected by the CSM were later approved by the credit officer, while another $25 \%$ accepted by the CSM were later rejected by the credit officer. Based on our hold-out sample, we illustrate this approach by setting two cut-offs for our CSMs, $C_{1}$ and $C_{2}$, with $0<C_{1}<C_{2}<1$. This calibration allows banks to define loans that require further examination instead of rejecting or accepting them outright. All loan applicants with an estimated $\mathrm{PD}<\mathrm{C}_{1}$ are accepted outright, whereas all applicants with an estimated $P D>C_{2}$ are rejected outright. The remaining loans with $\left(\mathrm{C}_{1}<\mathrm{PD}<\mathrm{C}_{2}\right)$ are classified as marginal and are thus reviewed by the credit officer. The bank's credit assessment can thus be a combination of transactional lending via CSMs and relationship lending.

Table 9 reports the results of this strategy for models 3 and $4 . C_{1}$ and $C_{2}$ are determined according to a somewhat ad hoc decision rule, which can be interpreted within the context of PCC. This rule specifies (1) that the proportion of incorrectly classified bad loans should be less than $20 \%$ of all bad loans, i.e., $B_{g} / B<20 \%$, and (2) that the proportion of correctly classified bad loans should be at least $50 \%$ of all bad loans, i.e., $B_{b} / B \geq 50 \%$. The emphasis on bad loans is justified by the relatively high penalty cost associated with overlooking bad loans. The benefit is the gain from reducing the number of good loans subjected to evaluation. We apply the above decision rule to both models 3 and 4 . This allows us to determine whether model 4 is more efficient than model 3: to achieve a given target of $\mathrm{B}_{\mathrm{g}} / \mathrm{B}$ and $\mathrm{B}_{\mathrm{b}} / \mathrm{B}$, according to the rule, would model 4 result in fewer applicants being reviewed

\footnotetext{
${ }^{16}$ For cost-saving motives, these lenders probably rely heavily, if not solely, on CSMs.
} 
manually than model 3 ? As shown in Table 9 , the cut-off points are $C_{1}=1.65 \%$ and $C_{2}=5 \%$ for model 3 and $\mathrm{C}_{1}=3 \%$ and $\mathrm{C}_{2}=6.5 \%$ for model 4 . Given these cut-off points, model 3 predicts 7,079 good loans, 5,168 marginal loans, and 2,159 bad loans, whereas model 4 predicts 9,135 good loans, 4,282 marginal loans, and 1,371 bad loans. Thus, if model 4 is used, the bank will need to manually review 4,282 applications compared with 5,168 applications with model 3 . By applying two cut-off points to the outcome of model 4, our bank can combine its transactional lending with relationship lending to achieve a pre-determined default target, yet improve its efficiency by minimizing the number of manual reviews. Thus, the updated postcrisis CSM improves not only the bank's profitability, as shown in the previous section, but also its efficiency.

[Insert Table 9 about here]

\subsection{Risk-based pricing}

In principle, a loan should be priced in accordance with the bank's cost of funds, origination costs, servicing costs, and implicit costs associated with potential default. While fixed costs do not generally vary within the same product category, expected default costs can vary across borrowers and should be calculated as PD times the loss given default (LGD). The risk-based interest rate $\mathrm{R}$ could thus be derived in a simple model as

$\mathrm{R}=$ cost of funds + overhead cost + expected default cost + profit margin

Because a crisis increases borrowers' default risk, a bank might respond by increasing interest rates, and because this increase in interest rates may in turn increase the bank's adverse selection problem, the overall effect might well be detrimental to the bank. An updated CSM, such as our model 4, enables the bank to better predict borrower default. A bank can thus improve the accuracy of its pricing strategy and thereby lessen the adverse selection problem. Based on our CSM, we can suggest a simple pricing strategy.

Given the cut-off point that maximizes the bank's profit - a cut-off point of $9.1 \%$ in the case of model 4 - any applicant with an estimated PD above $9.1 \%$ will be rejected. As Panel B of Table 10 shows, we split the bank's accepted borrowers into three risk classes containing approximately 4,750 borrowers each. The predicted PD for the low risk class ranges from $0.00 \%$ to $1.39 \%$, that for the moderate risk class from $1.40 \%$ to $3.12 \%$, and that for the high risk class from $3.13 \%$ to $9.09 \%$. Based on discussions with Vietnamese bankers, a 
$2.00 \%$ profit margin and an average $1.50 \%$ overhead cost appear to be reasonable and realistic assumptions. However, customers with higher risk usually generate higher costs because they tend to take up more of the credit officer's time. To be consistent with customer-specific pricing, overhead costs of $2.00 \%, 1.50 \%$, and $1.00 \%$ will be allocated to the high-, moderate-, and low-risk borrowers, respectively. The cost of funds can be approximated by the bank's deposit interest rate. In Vietnam, the annual deposit interest rate on local currency deposits between 2006 and 2010 ranged from $7.5 \%$ to $11.2 \%$, with an average of $9.3 \%$. Finally, the expected cost of default, PD*LGD, must be considered. Our CSM provides estimates for PD, but it is beyond the scope of this study to accurately estimate LGD. LGD will be at least loantype specific, as each type of loan is associated with a different type of collateral. However, nearly $99 \%$ of the collateral used in our data comprises real estate or savings certificates, both of which have a $100 \%$ recovery rate. Thus, we assume LGD on average is $20.2 \%$, the percentage of unsecured loans. Thus, default cost can be quite significant. As a benchmark, note that in 1997 risk premia for US consumer loans ranged from as low as $0.10 \%$ to more than $2.00 \%$ for the highest-risk borrowers (Sangha, 1998). In line with this study, we assign a $2.00 \%$ default cost to the high-risk borrowers, $0.20 \%$ to the moderate-risk borrowers and $0.10 \%$ to the low-risk borrowers. As Panel B in Table 10 shows, the bank could charge $12.40 \%, 13.00 \%$, and $15.30 \%$ to the different risk classes, respectively. If, on the other hand, the bank decides to charge the same price to all borrowers, it could charge an average interest rate of approximately $13.57 \%$ to obtain the same profit margin. As the second set of calculations shows, these assumptions would be fairly consistent with an LGD of $20.2 \%$ and a PD based on the realized PD of the risk class. In practice, PD could be based on the historic PD obtained from the loan portfolio used in estimating the CSM. ${ }^{17}$

To compare models 3 and 4 in terms of risk-based pricing, we repeat the above calculations, using the outcome of model 3 with the cut-off point of $9.1 \%$, which maximizes profitability under that model. The calculations are shown in Panel A of Table 10. When model 3 is used, the low risk class has a higher observed PD than the low risk class classified as such by model 4; therefore, the interest rate corresponding to low risk class classified by model 3 is estimated to be higher than that for model 4 . This is also the case for the moderate risk class. Thus, if the bank uses the outcome of the model constructed using pre-crisis data (model 3) to formulate its risk-based pricing policy, it will charge low-risk borrowers a relatively high interest rate while charging high-risk borrowers a relatively low interest rate

\footnotetext{
${ }^{17}$ For an in-depth analysis of the interactions among risk-based pricing, profit-maximizing cut-offs, and adverse selection problems, see Blöchlinger and Leippold (2006).
} 
compared with model 4. Thus, an updated CSM based on post-crisis data improves the bank's loan pricing ability and reduces its adverse selection problem.

[Insert Table 10 about here]

\section{Conclusions}

As banking markets in developing countries mature, banks face growing competition and increasing regulatory attention toward their risk management policies. Especially in the wake of the global financial crisis, banks have increasingly considered whether and how credit scoring can help them in these new circumstances. Based on our evidence from the Vietnamese retail loan market, the answer clearly favors credit scoring. First, after the crisis banks should update their CSMs, as the old CSMs, built on pre-crisis data, are no longer accurately predictive for the post-crisis population. Second, by replacing their current CSMs with properly updated CSMs, banks can expect a decrease in their default ratio even as profits improve. In addition, banks can use CSMs to implement risk-based pricing to manage loan portfolio composition. The updated CSM enables banks to set lower interest rates for borrowers that exhibit less credit risk. Thus, banks will be more competitive in this loan market segment and, by attracting more low-risk borrowers, will lessen the problem of adverse selection. Finally, an updated CSM reduces the costs in time spent by the loan officer in loan assessment. In contrast to corporate or government loans, retail loans are small and their credit assessment is more costly per $\$$ or VND of loan volume. A CSM can thus be calibrated with this consideration in mind. Overall, with updated CSMs banks can benefit from reduced loan default, increased competitiveness, and reduced cost of manual loan assessment while optimally using its relationship lending tools, i.e., the loan officer's knowledge about the borrower. Thus, it is important to regularly update CSMs, especially after a crisis, and align CSMs to the local market, as the predictive borrower-characteristics and their default probabilities are country-specific.

\section{Appendix A}

[Insert Table A-1 here] 


\section{Appendix B}

When categorizing and coding the variables, we must take the specific circumstances of Vietnam into account. The categories, as well as the PDs associated with all 17 variables, can be found in Table 4. Outlined below are the details regarding these categories in the first three models, the specific circumstances of Vietnam, the ways in which the categories of model 4 differ from those of model 3, and the reasons why we expect these borrower characteristics, i.e., those captured by the variables ultimately selected, to be relevant.

Regarding Education, we expect that better educated people will have more stable, higher-income employment and thus lower PDs. We therefore distinguish borrowers by their degree of educational attainment, ranging from post-graduate to non-high school graduate. In 2002 , however, less than $0.5 \%$ of the Vietnamese working population held a graduate or postgraduate degree and only $13 \%$ held an undergraduate degree (GSO, 2002). The largest share of the working population thus falls into the bottom two educational categories. Our loan sample broadly reflects these demographics but includes more highly educated borrowers: $40 \%$ of borrowers hold a post-graduate or graduate degree, $5 \%$ hold an undergraduate degree, $35 \%$ hold a high school degree and $20 \%$ have less or other education. Contradicting our expectations, default frequencies do not appear to decline with increasing education. College and high school graduates, for example, have the highest default frequency, namely, $6.53 \%$, followed by university graduates and post-graduates, with a default frequency of $5.11 \%$.

Gender can no longer be included in CSMs in many industrialized countries, as it is deemed discriminatory. In contrast, Schreiner (2003) argues that fair discrimination - for example, based on the statistical default rates of men versus women - is acceptable, as it is based on quantifiable data. The alternative - subjective scoring - discriminates equally if not more. Overall, there is ample evidence that women default less frequently than men on loans (Schreiner, 2004) but that most of this gender effect disappears when other risk factors correlated with gender are taken into account.18 We thus initially include gender and rely on the variable selection procedure to determine whether gender remains in the final CSM. In Vietnam, there is, furthermore, a specific relationship between gender and income that itself might be predictive of default. Specifically, the GSO (2004) reports higher income for women than for men. For wage earners, the average monthly income per month is 228 thousand VND, if the head of the household is a woman, and 139 thousand VND, if the head of the

\footnotetext{
${ }^{18}$ For Bolivian microfinance, Schreiner (2004) shows that women are less risky borrowers than men, as women are more likely to be traders than manufacturers and have smaller businesses that require smaller, shorter loans.
} 
household is a man. The same holds in the aggregate, when all income sources are combined. However, the aggregate differences between women and men are less pronounced, with women earning 589 thousand VND and men 489 thousand VND. ${ }^{19}$ It appears that women, who have higher average incomes than men, default less than men. Overall, default frequencies are $3.73 \%$ and $6.38 \%$ for women and men, respectively.

Region represents the area of the country where the borrower lives. Because people of similar wealth tend to live in the same location (a suburb might attract richer residents and the resulting increase in housing and property prices may make such a location prohibitively expensive for poorer households), this geographic criterion can indicate a borrower's level of financial wealth. A typical proxy is an area's postal code, but in Vietnam a postal code is not part of the address. Instead, we approximate region by the branch where a loan is issued. According to bank policy, borrowers can only obtain loans from their local branches. Branch location therefore coincides with the borrower's residential area. The many bank branches are located in eight regions, defined by the government. These eight regions are then categorized into four groups based on their average frequencies of default. Note that, given this coding, region might not only proxy for borrower's wealth but might also reflect the credit assessment capabilities of the different branches. In our sample, it appears that borrowers from the southeast (branches in Ho Chi Minh City contribute the most to this region) are the best borrowers, while those from the central part of the country are the worst. This pattern can be understood in terms of per capita income, which is highest in Ho Chi Minh City, followed by the north and south, while the center is the poorest area in Vietnam (World Bank 2004).

Time at current address represents the number of years that a borrower has resided at his current address. Crook et al. (1992) find that default risk drops with increases in this variable. Thus, time at present address might be a proxy for the borrower's maturity, stability, or risk aversion. However, this relationship does not hold in Vietnam, where default rates increase with time at present address. In Vietnam, people who acquire financial wealth tend to seek better living conditions and thus often move to a new home in a better area. Thus, changing addresses might be a signal that a borrower's financial wealth is high and/or improving rapidly. Under these conditions, he is better able to repay his loan.

Residential status indicates whether borrowers own their home, rent, or live with their parents. Errunza et al. (1981) finds that land ownership is a significant factor in predicting default. Ex ante, the relationship between residential status and default is unclear. On the one

\footnotetext{
${ }^{19}$ For this and all other binary variables, coding the variable based on equation (4) leads to a more precise measure than simply assigning values of 0 and 1 .
} 
hand, residential status can indicate financial wealth, particularly in the case of home ownership. On the other hand, residential status can indicate increased financial pressure on the borrower's income through insurance fees, taxes, or electricity costs. Crook et al. (1992) find that borrowers who are most likely to default belong to the "other" category, whereas borrowers living with their parents are least likely to default. We expect that this ranking will - be different for our sample, as the reasons for having a certain residential status in Vietnam are dissimilar from those in industrialized countries. Almost $90 \%$ of all borrowers in our sample own their homes, which properly reflects the Vietnamese population as a whole, where $95 \%$ of all households own their own home. Home ownership is somewhat higher in rural areas, at $98 \%$, compared with urban areas, where it is $86 \%$ (GSO 1999). If a home is used as collateral, as is likely when the borrower is a homeowner, default rates are among the lowest, whereas default rates are highest for tenants who do not own their homes. This pattern can be attributed to the importance of owning a home in Vietnamese culture, a norm that renders many Vietnamese borrowers averse to the prospect of losing their home.

Marital status can matter if it has an effect on the responsibility, reliability, or maturity of borrowers. In our sample, the default rate is lower for married than for single and widowed borrowers. We conjecture that clients without a spouse may be considered riskier than married clients, who take responsibility for a partner and perhaps also a family. Furthermore, married clients may be considered less risky because of possible dual incomes available for loan repayment. Another linkage exists between marital status and age. The Committee for Population, Family and Children (2003) found that in 2002 Vietnamese women married mainly in their $20 \mathrm{~s}$. Among 20 - to 24 -year old women, only $46 \%$ were married, compared with $80 \%$ to $90 \%$ of older women. Thus, the age group that shows the highest default rates (18 to 35 years) also has the most unmarried people. However, because $87 \%$ of borrowers are married, it is unclear ex ante how informative marital status will be compared with other variables such as age or income.

Loan purpose describes how borrowed funds are used. Generally speaking, pledging collateral reduces default risk. Most defaults occur in the uncollateralized or in the "other" loan purpose group. The "other" loan purpose group consists of credit card lending and loans undertaken with personal guarantees; $21.85 \%$ of these loans are collateralized with a physical asset, and $7.69 \%$ are in default. At the other end of the distribution, $98.62 \%$ of business loans are collateralized and only $2.88 \%$ are in default. Of the real-estate-related loans, $85.51 \%$ are collateralized and $3.19 \%$ are in default. Because a majority of pledged collateral is real estate, this fact might indicate borrower's risk aversion regarding the loss of his house and is also 
consistent with Vietnamese culture in which people view their homes as important aspects of their lives. Finally, there is an overlap between collateral type and residential status, as only borrowers who live in their own homes can use their homes as collateral. Note, however, that many borrowers who own more than one property use as collateral a property they do not reside in for (business) loans. This could again be a strong signal of the cultural importance of owning one's own home. As a related proxy, the collateral to loan ratio reflects the value of collateral relative to loan value. The higher this value, the greater the incentive for the borrower, who does not want to lose her collateral, to repay.

Loan duration measures the maturity of a loan in months. In preceding literature, Godquin (2004) establishes that loan duration is a significant determinant of repayment performance throughout all specifications. Usually, this feature of a loan results from negotiations between borrowers and banks and is thus excluded from CSMs. However, the Vietnamese situation is different. What we measure here is the loan duration as proposed by the borrower and not as negotiated between the bank and the borrower. This variable can thus be observed to reflect the borrower's intention, risk aversion, or self-assessment of repayment ability.

Time with bank measures the length of the banking relationship in years. Within the context of relationship lending, it can be assumed that the longer a customer stays with a bank, the more the bank knows about him and the lower the default risk becomes. However, while this relationship is confirmed for industrialized countries (Crook et al. 1992), it does not entirely hold in Vietnam. The highest default rates are found for those borrowers who have been with banks for 7 years or more, whereas for relationships of less than 7 years, the longer the relationship, the lower the default rate tends to be. This could reflect the fact that the Vietnamese banking market is in the process of reform and that credit officers still have room for preferential credit allocation. As reform progresses and CSMs are put into place, the effect of this variable is expected to change and should thus be reassessed regularly.

Number of prior loans counts the number of loans a customer was granted at the bank prior to the loan currently being considered. Many borrowers not only have a sequence of historical loans but also have taken out more than one loan at a time. Because a defaulted borrower has difficulty obtaining new loans, this proxy can be informative about default risk. As expected, default is least frequent for repeat borrowers: whereas $8.19 \%$ of first-time borrowers default, $3.67 \%$ of borrowers with one or two prior loans default, and only $0.49 \%$ of borrowers with more than 24 prior loans do so. This variable thus clearly reflects the importance of the bank-borrower relationship and a good credit record. 
Number of current accounts is a variable that indicates how many bank accounts the borrower currently holds at the bank. In Vietnam, the concept of a personal bank account is still unfamiliar to most of the population, with only approximately $6 \%$ of the population possessing a bank account in 2006. This percentage, however, is substantially higher for the urban middle class, at $35 \%$, and had increased substantially from only $12 \%$ in $2001 .^{20}$ In a recent conference on banking technology in Hanoi, it was reported that in 2012 approximately $20 \%$ of the population had a bank account; it is expected that this figure will increase to $35-$ $40 \%$ by $2015 .^{21}$ Having a bank account is largely indicative of a modern lifestyle among young people and may thus suggest education or financial wealth (see also Crook et al. 1992). In our sample, $50 \%$ of borrowers have one current account and another $23 \%$ have two or more accounts at the time of the loan request - both of these percentages are higher than the population average. These borrowers have a higher default risk. The high growth in current accounts might substantially change the relationship between default and current account ownership in the future. Consequently, this variable must be reassessed regularly if it is to be included in a CSM. ${ }^{22}$

Number of saving accounts is expected to be a strong predictor of default. Because the number of savings accounts at the bank is an indicator of a borrower's wealth, a higher number of savings accounts should reduce the default rate. In our data, borrowers without a savings account have the highest default rate of $6.56 \%$, whereas the default rate falls to only $0.77 \%$ for borrowers with more than nine savings accounts at the bank.

Occupation refers to the type of job the borrower has. It is classified into five groups. Surprisingly, the management group, which counts for $10.84 \%$ of borrowers, has the highest default rate $(7.16 \%)$, whereas the labor group and the retired and unemployed group have default rates of only $4.73 \%$ and $1.07 \%$, respectively. This may be explained by the fact that individuals in the management group may involve themselves in riskier projects than members of the other groups.

\footnotetext{
${ }^{20}$ Figures are obtained from two surveys conducted in 2006: (1) one by Visa International, as reported in the Thanh Nien News on January 8, 2007, and (2) TNS's VietCycle survey, as reported in the Vietnam Investment Review No 795 on January 8, 2007.

${ }^{21}$ Source: http://vneconomy.vn/20120320124414420P0C6/20-dan-so-viet-nam-co-tai-khoan-ngan-hang.htm

${ }^{22} \mathrm{We}$ also consider income, occupation, employer type, time with employer, age, and the ownership of a mobile phone. As these variables are not part of our final CSM, they are not described here in detail. These categories and their default frequencies are, however, listed in Tables 3 and A-1 for illustrative purposes.
} 


\section{References}

A D\&B, 2009. The Implications of the Global Credit crisis for credit scoring models. Decision Intellect Whitepaper, A Dun \& Bradstreet Company (A D\&B), available at http://www.decisionintellect.com.au

Akerlof, A., 1970. The Market for "Lemons": Quality Uncertainty and the Market Mechanism. The Quarterly Journal of Economics, Vol. 84( 3), 488-500.

Allen, L., DeLong, G., Saunders, A., 2004. Issues in credit risk modeling of retail markets. Journal of Banking and Finance 28, 727-752.

Altman, E.I., 1968. Financial ratios, discriminant analysis, and the prediction of corporate bankruptcy. Journal of Finance 23, 589-609.

Altman, E.I., Narayanan, P., 1997. An international survey of business failure classification models. Financial Markets, Institutions and Instruments 6, 1-57.

Altman, E.I., Saunders, A., 1998. Credit risk measurement: Developments over the last 20 years. Journal of Banking and Finance 21, 1721-1742.

Avery, R.B. Calem, P.S. and Canner, G.B., 2004. Consumer Credit Scoring: Do Situational Circumstances Matter?. Journal of Banking \& Finance 28, 835-856

Baesens, B., Gestel, T.V., Viaene, S., Stepanova, M., Suykens J., Vanthienen, J., 2003. Benchmarking state-of-the-art classification algorithms for credit scoring. Journal of the Operational Research Society 54, 627-635.

Bernanke, B.S. and Gertler, M., 1995. Inside the Black Box: The Credit Channel of Monetary Policy Transmission. Journal of Economic Perspectives 9, 27-48.

Blöchlinger, M., Leippold, M., 2006. Economic benefit of powerful credit scoring. Journal of Banking and Finance 30, 851-873.

Bonfim, D., 2009. Credit risk drivers: Evaluating the contribution of firm level information and of macroeconomic dynamics. Journal of Banking \& Finance, Volume 33, Issue 2 , 281-299.

Boyle, M., Crook, J.N., Hamilton, R., Thomas, L.C., 1992. Method s for credit scoring applied to slow payers, in: Thomas, L.C., Crook, J.N., Edelman, D.B. (Eds.), Credit Scoring and Credit Control. Oxford University Press, Oxford,75-90.

Byström, H., Worasinchai, L., Chongsithipol, S., 2005. Default risk, systematic risk and Thai firms before, during and after the Asian crisis. Research in International Business and Finance 19, 95-110.

Carling, K., Jacobson, T., Lindé, J., Roszbach, K., 2007. Corporate credit risk modeling and the macroeconomy. Journal of Banking \& Finance, Volume 31, Issue 3, 845-868. 
Committee for Population, Family and Children, ORC Macro, 2003. Vietnam Demographic and Health Survey 2002. Committee for Population, Family and Children, Hanoi, http://www.measuredhs.com/aboutsurveys/search/.

Cetorelli, N., Goldberg, L. Banking globalization and monetary transmission. Journal of Finance, forthcoming.

Cetorelli, N., Goldberg, L., 2011. Global banks and international shock transmission: evidence from the crisis. IMF Economic Review 59, 41-76.

Crook, J.N., Hamilton, R., Thomas, L.C., 1992. A comparison of discriminations under alternative definitions of credit default. In: Credit Scoring and Credit Control, Thomas, L.C., Crook, J.N., Edelman, D.B. Eds. Oxford University Press, Oxford, pp. 217-245.

Desai, V.S., Crook, J.N, Overstreet, G.A., 1996. A comparison of neutral networks and linear scoring models in the credit union environment. European Journal of Operational Research 95, 24-37.

Desai, V.S., Crook, J.N., Overstreet, G.A., 1997. Credit scoring models in the credit union environment using neutral networks and genetic algorithms. IMA Journal of Mathematics Applied in Business and Industry 8, 323-346.

Dinh, T.H.T., Kleimeier, S., 2007. A credit scoring model for Vietnam's retail banking market, International Review of Financial Analysis 16, 471-495.

Errunza, V. R., Calantone, R. J., Renforth, W. R., Strachan, H.W., 1981. Rural credit: A micro synthesis of the Salvadorean experience . Journal of Development Economics, Volume 8, Issue 2, 227-239.

GSO, 1999. Population and Housing Census Vietnam 1999. General Statistics Office of Vietnam (GSO), Hanoi, http://www.gso.gov.vn.

GSO, 2002. Establishment census of Vietnam 2002. General Statistics Office of Vietnam (GSO), Hanoi, http://www.gso.gov.vn.

GSO, 2004. Living standard survey 2004. General Statistics Office of Vietnam (GSO), Hanoi, http://www.gso.gov.vn.

Godquin, M., 2004. Microfinance Repayment Performance in Bangladesh: How to Improve the Allocation of Loans by MFIs. World Development, Volume 32, Issue 11, 19091926.

Goetz, A.M., Gupta, R.S., 1996. Who takes the credit? Gender, power, and control over loan use in rural credit programs in Bangladesh. World Development, Volume 24, Issue 1, 45-63. 
Hans Dellien and Mark Schreiner, 2005. Credit Scoring, Banks, and Microfinance: Balancing High-Tech with High-Touch. http://www.microfinance.com/English/Papers.

Herrmann, S., Mihaljek, D., 2010. The determinants of cross-border bank flows to emerging markets: new empirical evidence on the spread of financial crises. BIS Working Papers No 315.

Henley, W.E., 1995. Statistical aspects of credit scoring. Open University, Dissertation.

Henley, W.E., Hand, D.J., 1997. Statistical classification methods in consumer credit scoring: a review. Journal of the Royal Statistical Society - Series A (Statistics in Society) 160 , 523-541.

Ivashina, V., Scharfstein, D., 2010. Bank lending during the financial crisis of 2008. Journal of Financial Economics 97 (3), 319-338.

Jankowitsch R., Pichler S., Schwaiger W.S.A., 2007, Modelling the economic value of credit rating systems - Journal of Banking \& Finance, Volume 31, Issue 1, January 2007, Pages 181-198.

Kirabaeva, K., 2011. Adverse Selection and Financial Crises. Bank of Canada Review, vol. 2010-2011, issue Winter, 11-19.

Kraznowski, W. J., Hand, D. J., 2009. ROC Curves for Continuous Data. Taylor \& Francis, Inc. Boca Raton.

Laitinen, E.K., 1999. Predicting a corporate credit analyst's risk estimate by logistic and linear models. International Review of Financial Analysis 8, 97-121.

Loi, H.T., 2006. Credit risk and credit access in Asia: Trends and developments in insolvency system and risk management: The experience of Vietnam. Source OECD Emerging Economies 2006(8), 281-289.

Lucas, A., Klaassen, P., 2006. Discrete versus continuous state switching models for portfolio credit risk - Journal of Banking \& Finance, Volume 30, Issue 1, 23-35.

Mester, L., 1997. What's the point of credit scoring? Federal Reserve Bank of Philadelphia Business Review, September/October, 3-16.

Milesi-Ferretti, G.M., Tille, C., 2011. The great retrenchment: international capital flows during the global financial crisis. Economic Policy 26 (66), 289-346.

Miller, M., Rojas, D., 2004. Improving access to credit for SMEs: An empirical analysis of the viability of pooled data SME credit scoring models in Brazil, Colombia \& Mexico. Working paper, http://siteresources.worldbank.org/[NTFR/Resources/4754591107891190953/661910-1108584820141/Miller_ImprovingAccesstoCredit.pdf 
Philosophov, L.V., Philosophov, V.L., 2002, Corporate bankruptcy prognosis: An attempt at a combined prediction of the bankruptcy event and time interval of its occurrence, International Review of Financial Analysis 11, 375-406.

Provost, F., Fawcett, T., Kohavi, R., 1998. The case against accuracy estimation for comparing classifiers. Proceedings of the Fifteenth International Conference on Machine Learning, 445-553.

Popov, A., Udell, G., 2012. Cross-border banking, credit access, and the financial crisis. Journal of International Economics 87 (1), 147-161.

Quach, L.T., 2011, Banking sector report. Vietcombank Securities, Research and Analysis Department, September, available at http://vninvestment.files.wordpress.com/2012/ 03/vietnambank2011.pdf.

Ryo, H., Hideaki, H., Arito, O., 2011. Differentiated Use of Small Business Credit Scoring by Relationship Lenders and Transactional Lenders: Evidence from firm-bank matched data in Japan. RIETI Discussion Paper Series 11-E-070

Sangha, B.S., 1998. A systematic approach for managing credit score overrides, in: Mays, E. (Ed.), Credit Risk Modeling Design and Application. Glenlake Publishing, Chicago, pp. 223-244.

Schreiner, M., 2003. Scoring: The next breakthrough in microcredit? CGAP Occasional Paper No. 7, http://www.cgap.org.

Schreiner, M., 2004. Scoring arrears at a microlender in Bolivia. Journal of Microfinance 6, 65-88.

Srinivasan, V., Kim, Y.H., 1987. The Bierman-Hausman credit granting model: A note. Management Science 33, 1361-1362.

Stiglitz, Joseph E., and Andrew Weiss, 1981. Credit Rationing in Markets with Imperfect Infor- mation. American Economic Review 71, 393-410.

Takats, E., 2010. Was it credit supply? Cross-border bank lending to emerging market economies during the financial crisis. BIS Quarterly Review (June), 49-56.

Thomas L.C., 2000. A survey of credit and behavioral scoring: Forecasting financial risk of lending to consumers. International Journal of Forecasting 16, 149-172.

Viganó, L., 1993. A credit scoring model for development banks: An African case study. Savings and Development 4, 441-482.

Vogelgesang, U., 2003. Microfinance in Times of Crisis: The Effects of Competition, Rising Indebtedness, and Economic Crisis on Repayment Behavior. World Development, Volume 31, Issue 12, 2085-2114. 
Yobas, M.B., Crook, J.N., Ross, P., 2000. Credit scoring using neural and evolutionary techniques. IMA Journal of Mathematics Applied in Business and Industry 11, 111125. 


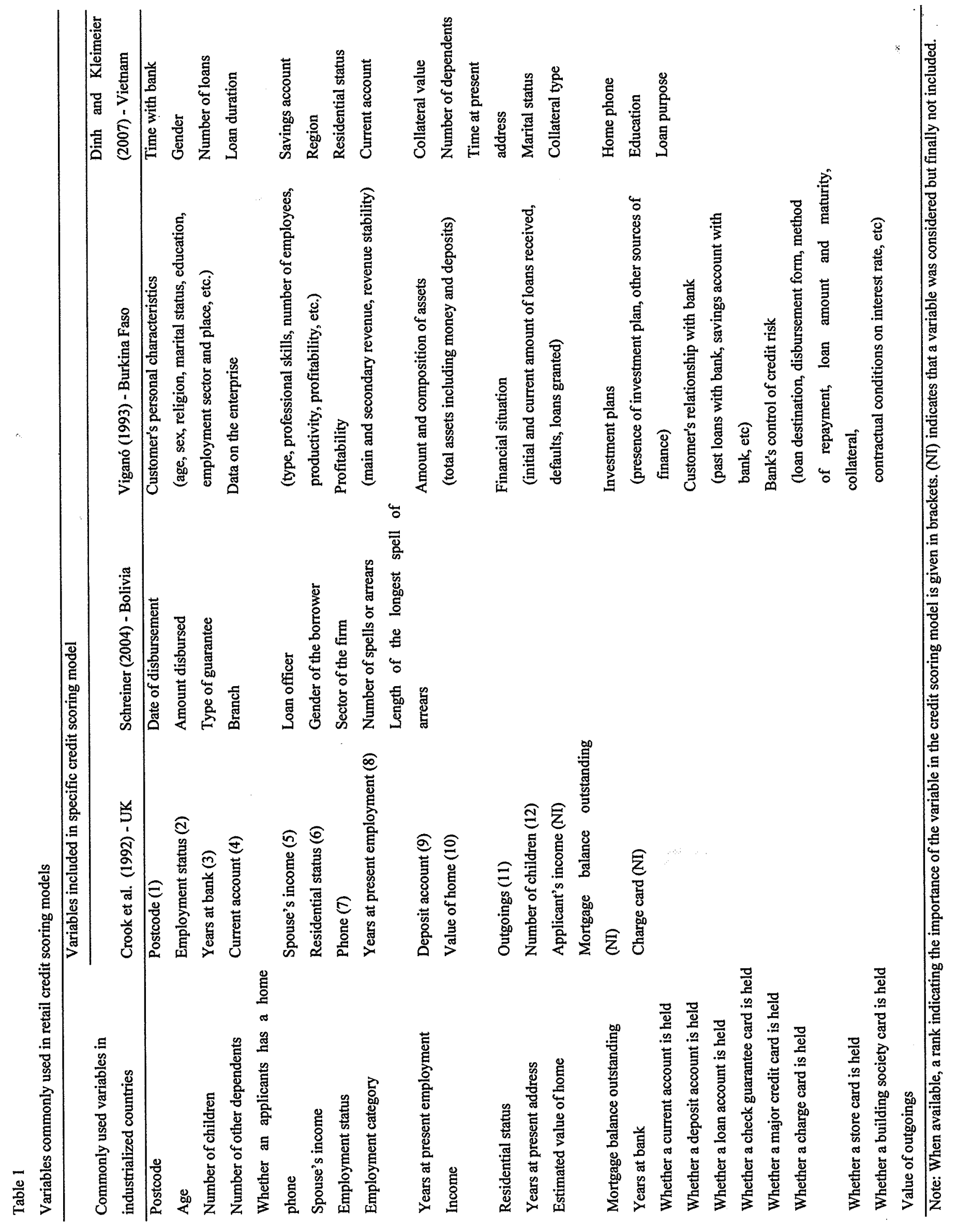


Table 2

Predictive accuracy of credit scoring models

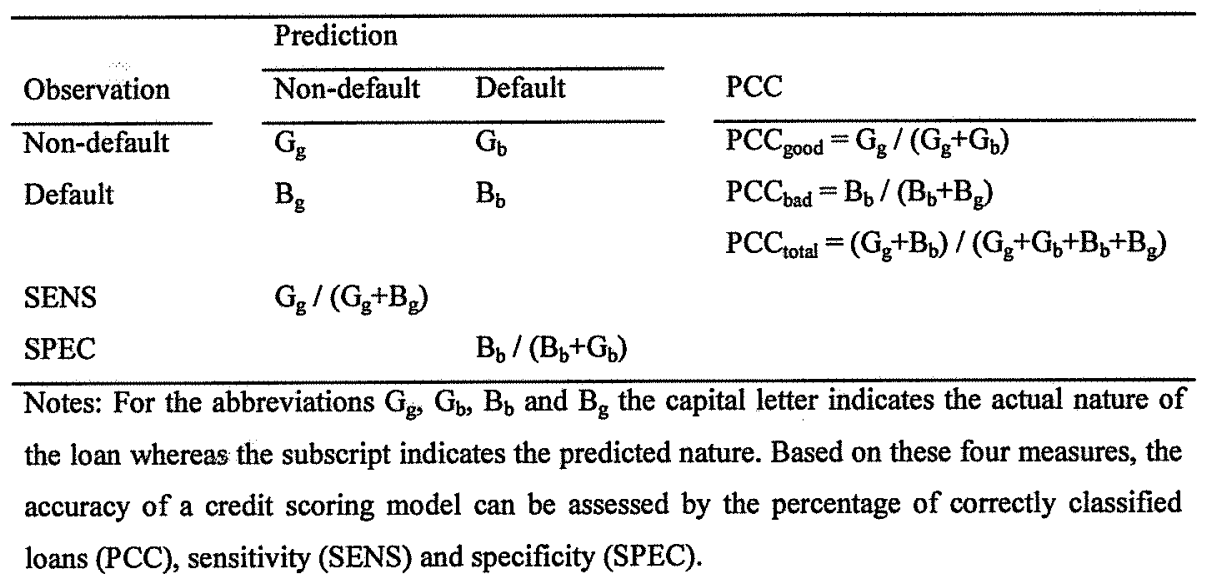

Table 3

Descriptive statistics

\begin{tabular}{|c|c|c|c|c|c|c|c|c|}
\hline \multicolumn{9}{|c|}{ Panel A: Characteristics of the bank's loan portfolio } \\
\hline \multirow[b]{2}{*}{ Sample } & \multirow[b]{2}{*}{ \# Loans } & \multirow[b]{2}{*}{ Default frequency } & \multicolumn{2}{|c|}{ Loan size (million VND) } & \multicolumn{4}{|c|}{ Distribution of loans across loan purpose } \\
\hline & & & Average & Std. Dev. & Commercial & Consumer & Real estate & Other \\
\hline Pre crisis & 25,302 & $5.3 \%$ & 239.0 & 717.6 & $21 \%$ & $14 \%$ & $40 \%$ & $24 \%$ \\
\hline Crisis & 7,432 & $4.1 \%$ & 279.7 & 677.5 & $16 \%$ & $28 \%$ & $41 \%$ & $15 \%$ \\
\hline Post crisis & 18,704 & $2.6 \%$ & 420.7 & $1,524.0$ & $22 \%$ & $33 \%$ & $34 \%$ & $10 \%$ \\
\hline Out-of-sample & 14,788 & $2.6 \%$ & 428.5 & $1,103.1$ & $19 \%$ & $38 \%$ & $33 \%$ & $10 \%$ \\
\hline Total & 66,226 & $3.8 \%$ & 402.4 & $1,311.1$ & $20 \%$ & $26 \%$ & $37 \%$ & $16 \%$ \\
\hline
\end{tabular}

\begin{tabular}{|c|c|c|c|c|c|c|c|c|}
\hline \multirow[b]{2}{*}{ Average characteristic } & \multicolumn{2}{|c|}{ Pre-crisis } & \multicolumn{2}{|l|}{ Crisis } & \multicolumn{2}{|c|}{ Post-crisis } & \multicolumn{2}{|c|}{ Out-of-sample } \\
\hline & default & non-default & default & non-default & default & non-default & default & non-default \\
\hline Income(million VND) & 12.49 & 24.63 & 21.09 & 31.50 & 64.26 & 47.11 & 38.06 & 50.18 \\
\hline Age (years) & 35.52 & 38.26 & 36.01 & 39.76 & 39.79 & 40.49 & 38.30 & 41.15 \\
\hline Time at current address (years) & 7.12 & 6.89 & 9.72 & 6.42 & 6.77 & 5.89 & 5.99 & 6.80 \\
\hline Time at current jobs (years) & 6.04 & 5.71 & 4.96 & 5.22 & 4.70 & 5.30 & 4.16 & 5.01 \\
\hline Loan duration (months) & 41.80 & 45.80 & 42.46 & 39.50 & 58.98 & 48.38 & 54.90 & 46.83 \\
\hline Time with bank (years) & 1.05 & 1.77 & 1.43 & 2.29 & 1.98 & 2.58 & 1.69 & 2.81 \\
\hline Number of prior loans & 0.85 & 5.35 & 2.15 & 8.11 & 20.19 & 14.42 & 8.19 & 14.28 \\
\hline Number of current accounts & 0.94 & 1.39 & 1.27 & 1.78 & 5.12 & 3.61 & 2.71 & 3.00 \\
\hline Number of saving accounts & 0.55 & 3.87 & 0.93 & 5.56 & 7.53 & 10.52 & 3.31 & 10.86 \\
\hline Collateral-Loan value index & 0.50 & 1.35 & 0.92 & 2.11 & 2.32 & 2.37 & 2.05 & 2.53 \\
\hline
\end{tabular}


Table 4

Loan and borrower characteristics considered for the credit scoring model

\begin{tabular}{|c|c|c|c|c|c|}
\hline \multirow{2}{*}{$\begin{array}{l}\text { Variable } \\
\text { Age }\end{array}$} & \multicolumn{5}{|c|}{ Categories and default frequencies } \\
\hline & 18 to 35 & 36 to 50 & more than 51 & & missing \\
\hline & $6.51 \%$ & $4.68 \%$ & $2.65 \%$ & & $7.14 \%$ \\
\hline \multirow[t]{2}{*}{ Gender } & male & female & & & \\
\hline & $6.38 \%$ & $3.73 \%$ & & & \\
\hline \multirow[t]{2}{*}{ Marital status } & married & single & widowed & divorced & $*$ \\
\hline & $4.45 \%$ & $7.81 \%$ & $4.52 \%$ & $8.39 \%$ & \\
\hline \multirow[t]{2}{*}{ Education } & $\begin{array}{l}\text { university graduate, } \\
\text { post graduate }\end{array}$ & $\begin{array}{l}\text { college, high school } \\
\text { graduate }\end{array}$ & $\begin{array}{l}\text { occupational school } \\
\text { graduate }\end{array}$ & & missing \\
\hline & $5.11 \%$ & $6.53 \%$ & $3.22 \%$ & & $2.66 \%$ \\
\hline \multirow[t]{3}{*}{ Resident status } & house owner & tenant & living with & & missing \\
\hline & & & parents/relatives \& other & & \\
\hline & $3.23 \%$ & $8.30 \%$ & $8.04 \%$ & & $16.07 \%$ \\
\hline Time at current address & less than 1 & 2 to 15 & more than 16 & & missing \\
\hline (years) & $5.59 \%$ & $4.61 \%$ & $5.65 \%$ & & $3.70 \%$ \\
\hline \multirow[t]{2}{*}{ Income (million VND) } & less than 5 & 5 to 10 & more than 10 & & missing \\
\hline & $9.07 \%$ & $5.68 \%$ & $2.87 \%$ & & $4.40 \%$ \\
\hline \multirow[t]{2}{*}{ Occupation } & management & labor work & retired, unemployed & other & missing \\
\hline & $7.16 \%$ & $4.73 \%$ & $1.07 \%$ & $5.45 \%$ & $6.78 \%$ \\
\hline Time at current employer & less than 1 & 1 to 9 & 10 to 20 & more than 21 & missing \\
\hline (years) & $2.89 \%$ & $8.10 \%$ & $4.78 \%$ & $7.21 \%$ & $4.82 \%$ \\
\hline \multirow[t]{2}{*}{ Loan purpose } & commercial & consumer & real estate & other & \\
\hline & $2.88 \%$ & $5.81 \%$ & $3.19 \%$ & $7.69 \%$ & \\
\hline \multirow[t]{2}{*}{ Loan duration (months) } & 1 to 12 & 13 to 48 & 49 to 120 & more than 120 & \\
\hline & $1.55 \%$ & $6.83 \%$ & $3.74 \%$ & $2.78 \%$ & \\
\hline \multirow[t]{2}{*}{ Collateral-Loan value index } & 0 & more than 0 up to 1 & more than 1 up to 1.5 & more than 1.5 up to 5 & $\begin{array}{l}\text { more } \\
\text { than } 5\end{array}$ \\
\hline & $7.50 \%$ & $2.75 \%$ & $3.07 \%$ & $2.30 \%$ & $1.59 \%$ \\
\hline \multirow[t]{2}{*}{ Time with bank (years) } & 0 & 1 to 2 & 3 to 6 & more than 7 & \\
\hline & $7.16 \%$ & $4.33 \%$ & $2.87 \%$ & $5.62 \%$ & \\
\hline \multirow[t]{2}{*}{ Number of prior loans } & 0 & 1 to 2 & 3 to 7 & 8 to 23 & $\begin{array}{l}\text { more } \\
\text { than } 24\end{array}$ \\
\hline & $8.19 \%$ & $3.67 \%$ & $2.04 \%$ & $1.28 \%$ & $0.49 \%$ \\
\hline \multirow[t]{2}{*}{ Number of current accounts } & 0 & 1 & 2 & more than 3 & \\
\hline & $4.08 \%$ & $8.06 \%$ & $2.57 \%$ & $1.28 \%$ & \\
\hline \multirow[t]{2}{*}{ Number of saving account } & 0 & 1 to 3 & 4 to 8 & more than 9 & \\
\hline & $6.56 \%$ & $3.15 \%$ & $1.72 \%$ & $0.77 \%$ & \\
\hline \multirow[t]{2}{*}{ Region } & $\begin{array}{l}\text { central highland, } \\
\text { south central coast }\end{array}$ & south east & Red river delta & $\begin{array}{l}\text { Mekong delta river, } \\
\text { north central coast, } \\
\text { north east }\end{array}$ & missing \\
\hline & $9.09 \%$ & $5.12 \%$ & $7.39 \%$ & $9.56 \%$ & $6.78 \%$ \\
\hline
\end{tabular}

Note: In Panel C, the categories of each independent variable considered for the CSM are shown in the top rows followed by the default probabilities in the bottom row in italics. 
Table 5

The estimated credit scoring model

\begin{tabular}{|c|c|c|c|c|c|c|c|c|}
\hline \multirow{3}{*}{ Intercept } & \multirow{2}{*}{\multicolumn{2}{|c|}{$\begin{array}{c}\text { Model } 1 \\
\text { pre-crisis, } \\
\text { crisis, } \\
\text { and post-crisis } \\
\text { samples }\end{array}$}} & \multicolumn{2}{|c|}{ Model 2} & \multicolumn{2}{|c|}{ Model 3} & \multicolumn{2}{|l|}{ Model 4} \\
\hline & & & \multicolumn{2}{|c|}{$\begin{array}{c}\text { pre-crisis, } \\
\text { and post-crisis } \\
\text { samples }\end{array}$} & \multicolumn{2}{|c|}{$\begin{array}{c}\text { pre-crisis } \\
\text { sample }\end{array}$} & \multicolumn{2}{|c|}{$\begin{array}{l}\text { post-crisis } \\
\text { sample }\end{array}$} \\
\hline & -1.66 & $* * *$ & -1.15 & $* * *$ & -1.60 & $* * *$ & -1.88 & *** \\
\hline & -100.44 & & -32.45 & & -112.67 & & -91.88 & \\
\hline \multirow[t]{2}{*}{ Gender } & -0.31 & $* * *$ & -0.28 & $* * *$ & -0.34 & $* * *$ & -0.31 & $* *$ \\
\hline & -7.37 & & -5.89 & & -6.52 & & -2.53 & \\
\hline \multirow[t]{2}{*}{ Marital status } & -0.18 & $* * *$ & -0.19 & $* * *$ & -0.18 & $* * *$ & -0.26 & $* * *$ \\
\hline & -5.39 & & -5.05 & & -3.50 & & -3.65 & \\
\hline \multirow[t]{2}{*}{ Education } & -0.11 & $* *$ & & & -0.19 & $* * *$ & & \\
\hline & -2.19 & & & & -2.90 & & & \\
\hline \multirow[t]{2}{*}{ Resident status } & -0.18 & $* * *$ & -0.18 & $* * *$ & -0.14 & $* * *$ & & \\
\hline & -7.54 & & -7.44 & & -4.18 & & & \\
\hline \multirow[t]{2}{*}{ Time at current address } & & & -0.15 & $*$ & & & -0.41 & $* * *$ \\
\hline & & & -1.67 & & & & -4.67 & \\
\hline \multirow[t]{2}{*}{ Income } & & & & & -0.11 & $* * *$ & & \\
\hline & & & & & -3.19 & & & \\
\hline \multirow[t]{2}{*}{ Occupation } & -0.43 & $* * *$ & -0.24 & $* * *$ & & & & \\
\hline & -6.52 & & -7.90 & & & & & \\
\hline \multirow[t]{2}{*}{ Time at current employer } & -0.19 & $* * *$ & -0.18 & $* * *$ & -0.51 & $* * *$ & -0.24 & $* * *$ \\
\hline & -5.48 & & -4.78 & & -11.64 & & -3.40 & \\
\hline \multirow[t]{2}{*}{ Loan duration } & -0.15 & $* * *$ & -0.11 & $* * *$ & & & -0.36 & $* * *$ \\
\hline & -6.15 & & -3.76 & & & & -5.66 & \\
\hline \multirow[t]{2}{*}{ Collateral-Loan value index } & -0.08 & $* *$ & & & -0.06 & $*$ & -0.14 & $* *$ \\
\hline & -2.94 & & & & -1.68 & & -2.17 & \\
\hline \multirow[t]{2}{*}{ Time with bank } & -0.06 & $* *$ & -0.10 & $* * *$ & & & -0.26 & $* * *$ \\
\hline & -2.21 & & -3.43 & & & & -4.87 & \\
\hline \multirow[t]{2}{*}{ Number of prior loans } & -0.14 & $* * *$ & -0.14 & $* * *$ & -0.20 & $* * *$ & -0.22 & $* * *$ \\
\hline & -5.61 & & -5.22 & & -6.49 & & -4.37 & \\
\hline \multirow[t]{2}{*}{ Number of current accounts } & -0.12 & $* * *$ & -0.11 & $* * *$ & -0.16 & $* * *$ & & \\
\hline & -4.57 & & -4.10 & & -5.08 & & & \\
\hline \multirow[t]{2}{*}{ Number of saving accounts } & -0.23 & $* * *$ & -0.21 & $* * *$ & -0.24 & $* * *$ & -0.21 & $* * *$ \\
\hline & -9.27 & & -8.07 & & -7.52 & & -3.67 & \\
\hline \multirow[t]{2}{*}{ Region } & -0.30 & $* * *$ & -0.31 & $* * *$ & -0.21 & $* *$ & -0.26 & $* * *$ \\
\hline & -4.64 & & -4.25 & & -2.03 & & -2.92 & \\
\hline log likelihood & $-8,128$ & & $-6,980$ & & $-4,767$ & & $-2,108$ & \\
\hline pseudo $R^{2}$ & 0.580 & & 0.833 & & 0.591 & & 0.689 & \\
\hline number of observations & 51,438 & & 44,006 & & 25,302 & & 18,704 & \\
\hline
\end{tabular}

Note: This table shows the models estimated by probit regression. The dependent variable is a dummy equal to one for defaulted loans and zero otherwise. For each independent variable, the first row shows the coefficient and the second row shows the z statistic. $* * *, * *$, and $*$ indicate statistical significance at the $1 \%, 5 \%$, and $10 \%$ level, respectively. 
Table 6

Model predictive performance

\begin{tabular}{|c|c|c|c|c|c|}
\hline \multirow[b]{3}{*}{ Model 1} & \multirow[b]{2}{*}{ estimation sample } & \multicolumn{2}{|c|}{ Predictive statistic GINI } & \multicolumn{2}{|c|}{ Predictive statistic AUC } \\
\hline & & In sample & Hold-out sample & In sample & Hold-out sample \\
\hline & pre-crisis, crisis, post-crisis & $47.60 \%$ & $20.80 \%$ & $73.80 \%$ & $60.40 \%$ \\
\hline Model 2 & pre-crisis, post-crisis & $47.00 \%$ & $22.08 \%$ & $73.50 \%$ & $61.04 \%$ \\
\hline Model 3 & pre-crisis & $47.80 \%$ & $12.00 \%$ & $73.90 \%$ & $56.00 \%$ \\
\hline Model 4 & post-crisis & $44.56 \%$ & $26.22 \%$ & $72.28 \%$ & $63.11 \%$ \\
\hline
\end{tabular}

Note: The table shows two predictive statistics that are commonly used to assess CSM performance by banks. The higher these statistics the more predictive the CSM is. 
Table 7

Goodness of fit based on predicted versus observed probabilities of default in the hold-out sample

\begin{tabular}{|c|c|c|c|c|c|}
\hline \multicolumn{6}{|c|}{ Default probabilities by loan groups } \\
\hline \multirow{3}{*}{$\begin{array}{l}\text { Loan } \\
\text { Group }\end{array}$} & \multirow[b]{3}{*}{ \# Loans } & \multicolumn{4}{|c|}{ Probability of default (in \%) } \\
\hline & & \multirow[b]{2}{*}{ Observed } & \multicolumn{3}{|c|}{ Predicted } \\
\hline & & & Min & Mean & $\operatorname{Max}$ \\
\hline \multicolumn{6}{|c|}{ Panel A: Model 3 based on pre-crisis sample } \\
\hline$T$ & 2,959 & 1.08 & 0.03 & 0.31 & 0.58 \\
\hline 2 & 2,958 & 1.52 & 0.58 & 0.91 & 1.25 \\
\hline 3 & 2,980 & 1.28 & 1.25 & 1.75 & 2.34 \\
\hline 4 & 2,934 & 2.59 & 2.34 & 3.23 & 4.31 \\
\hline 5 & 2,957 & 6.46 & 4.31 & 7.10 & 31.53 \\
\hline Total & 14,788 & 2.58 & 0.02 & 2.66 & 31.53 \\
\hline \multicolumn{2}{|c|}{ Non-default } & & 0.03 & 2.53 & 21.82 \\
\hline \multicolumn{2}{|c|}{ Default } & & 0.34 & 7.25 & 31.53 \\
\hline \multicolumn{6}{|c|}{ Panel B: Model 4 based on post-crisis sample } \\
\hline 1 & 2,958 & 0.74 & 0.00 & 0.45 & 0.91 \\
\hline 2 & 2,972 & 0.57 & 0.91 & 1.31 & 1.75 \\
\hline 3 & 2,944 & 1.29 & 1.75 & 2.28 & 2.86 \\
\hline 4 & 2,957 & 1.29 & 2.86 & 3.61 & 4.51 \\
\hline 5 & 2,957 & 9.03 & 4.52 & 7.13 & 24.69 \\
\hline Total & 14,788 & 2.58 & 0.00 & 2.95 & 24.69 \\
\hline \multicolumn{2}{|c|}{ Non-default } & & 0.00 & 2.37 & 23.37 \\
\hline \multicolumn{2}{|l|}{ Default } & & 0.40 & 8.24 & 24.69 \\
\hline
\end{tabular}

Note: This table shows predicted probability of default versus observed frequency of default. Loans are ranked and grouped into 5 groups according to the predicted probability of default. Average of predicted probability and observed frequency of default are calculated and shown here. 
Table 8

Predictive accuracy for credit scoring models with one cut-off

Panel A: Predictive accuracy of model 3 with a pre-specified cut-off $(5.3 \%)$ to achieve a target PD of $1.5 \%$

\begin{tabular}{lllll}
\hline \multirow{2}{*}{ Observed } & Predicted & & \\
\cline { 2 - 3 } & Non-default & Default & & PCC \\
\hline Non-default & 12521 & 1885 & $86.92 \%$ & $=$ PCCgood \\
Default & 192 & 190 & $49.74 \%$ & $=$ PCCbad \\
& & & $84.67 \%$ & $=$ PCCttal
\end{tabular}

SENS $\quad 98.5 \%$

SPEC

Change in Profit 404 mil VND

Panel B: Predictive accuracy of model 4 with a pre-specified cut-off ( $7.4 \%)$ to achieve a target PD of $1.5 \%$

\begin{tabular}{lllll}
\hline \multirow{2}{*}{ Observed } & Predicted & & \multirow{2}{*}{ PCC } \\
\cline { 2 - 4 } & Non-default & Default & & = \\
\hline Non-default & 13,625 & 781 & $94.58 \%$ & $=$ PCgood \\
Default & 207 & 175 & $45.81 \%$ & $=$ PCCbad \\
& & & $93.32 \%$ & $=$ PCCttal
\end{tabular}

SENS $\quad 98.5 \%$

SPEC

$18.3 \%$

Change in profit $\quad 26,124 \mathrm{mil} \mathrm{VND}$

\begin{abstract}
Note: This table shows how well the model 3 and 4 can predict probability of default and how accurate they can identify defaulted and non-defaulted loans. To calculate the economic benefit made by these models we assume that the cost per bad loan is ten times the benefit per good loan and the annual margin is $2 \%$. Given the average loan amount of VND 337 million and the average loan duration of 48 months the change in profit can be estimated using the equation: $\Delta$ profit $=$ cost per bad loan* B b - benefit per good loan*G_b.
\end{abstract}


Table 9

Predictive accuracy for credit scoring models with two cut-offs

\begin{tabular}{|c|c|c|c|}
\hline \multirow[b]{2}{*}{ Observed } & \multicolumn{3}{|c|}{ Predictied } \\
\hline & Non-default & Marginal & Default \\
\hline Non-default & 7,079 & 5,168 & 2,159 \\
\hline Default & 79 & 112 & 191 \\
\hline $\mathrm{B}_{\mathrm{g}} / \mathrm{B}$ & $20.7 \%$ & & \\
\hline $\mathrm{B}_{\mathrm{b}} / \mathrm{B}$ & & & $50 \%$ \\
\hline
\end{tabular}

Panel B: Model 4 with two cut-offs at 0.03 and 0.065

\begin{tabular}{lrrr}
\hline & \multicolumn{3}{c}{ Predictied } \\
\cline { 2 - 4 } Observed & Non-default & Marginal & Default \\
\hline Non-default & 9,056 & 4,170 & 1,180 \\
Default & 79 & 112 & 191 \\
$\mathrm{~B}_{\mathrm{g}} / \mathrm{B}$ & & & \\
$\mathrm{B}_{\mathrm{b}} / \mathrm{B}$ & $20.7 \%$ & & $50 \%$
\end{tabular}

Note: This table shows how accurate models 3 and 4 can identify defaulted and non-defaulted loans if two cut-off points are applied and how many applications should be referred to loan officers to be assessed manually. 
Table 10

Risk -based loan pricing

\begin{tabular}{|c|c|c|c|c|}
\hline & \multicolumn{3}{|c|}{ Borrower class } & \multirow[b]{2}{*}{ All borrowers } \\
\hline & Low risk & Moderate risk & High risk & \\
\hline \multicolumn{5}{|c|}{ Panel A: Model 3 based on pre-crisis sample } \\
\hline Range of predicted PD & $0.03 \%-0.97 \%$ & $0.97 \%-3.64 \%$ & $2.64 \%-9.09 \%$ & $0.00 \%-9.09 \%$ \\
\hline Number of loans & 4,776 & 4,772 & 4,772 & 14,320 \\
\hline Overhead cost & $1.00 \%$ & $1.50 \%$ & $2.00 \%$ & $1.50 \%$ \\
\hline Cost of funds & $9.30 \%$ & $9.30 \%$ & $9.30 \%$ & $9.30 \%$ \\
\hline Profit margin & $2.00 \%$ & $2.00 \%$ & $2.00 \%$ & $2.00 \%$ \\
\hline Cost of default & $0.10 \%$ & $0.20 \%$ & $2.00 \%$ & $0.77 \%$ \\
\hline Loan interest rate & $12.40 \%$ & $13.00 \%$ & $15.30 \%$ & $13.57 \%$ \\
\hline$L D=$ average observed $P D$ & $0.92 \%$ & $1.57 \%$ & $3.02 \%$ & $1.84 \%$ \\
\hline LGD & $20.20 \%$ & $20.20 \%$ & $20.20 \%$ & $20.20 \%$ \\
\hline Cost of default $=L D * L G D$ & $0.19 \%$ & $0.32 \%$ & $0.61 \%$ & $0.37 \%$ \\
\hline Loan interest rate & $12.49 \%$ & $13.12 \%$ & $13.91 \%$ & $13.17 \%$ \\
\hline \multicolumn{5}{|c|}{ Panel B: Model 4 based on post-crisis sample } \\
\hline Range of predicted PD & $0.00 \%-1.39 \%$ & $1.40 \%-3.12 \%$ & $3.13 \%-9.09 \%$ & $0.00 \%-9.09 \%$ \\
\hline Number of loans & 4,759 & 4,767 & 4,747 & 14,273 \\
\hline Overhead cost & $1.00 \%$ & $1.50 \%$ & $2.00 \%$ & $1.50 \%$ \\
\hline Cost of funds & $9.30 \%$ & $9.30 \%$ & $9.30 \%$ & $9.30 \%$ \\
\hline Profit margin & $2.00 \%$ & $2.00 \%$ & $2.00 \%$ & $2.00 \%$ \\
\hline Cost of default & $0.10 \%$ & $0.20 \%$ & $2.00 \%$ & $0.77 \%$ \\
\hline Loan interest rate & $12.40 \%$ & $13.00 \%$ & $15.30 \%$ & $13.57 \%$ \\
\hline $\mathrm{LD}=$ average observed $\mathrm{PD}$ & $0.82 \%$ & $0.94 \%$ & $3.10 \%$ & $1.62 \%$ \\
\hline LGD & $20.20 \%$ & $20.20 \%$ & $20.20 \%$ & $20.20 \%$ \\
\hline Cost of default $=L D * L G D$ & $0.17 \%$ & $0.19 \%$ & $0.63 \%$ & $0.33 \%$ \\
\hline Loan interest rate & $12.47 \%$ & $12.99 \%$ & $13.93 \%$ & $13.13 \%$ \\
\hline
\end{tabular}

Note: The abbreviations are probability of default (PD) and loss given default (LGD). 
Figure 1

ROC curve

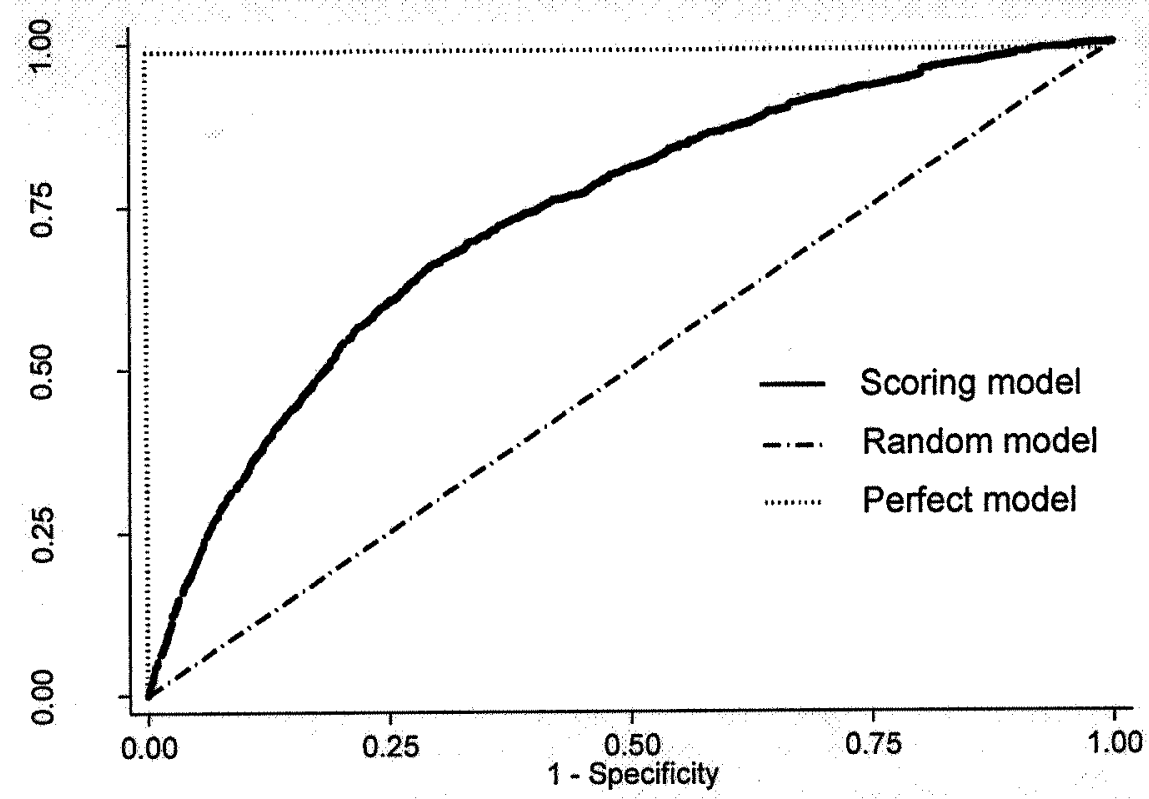

Note: This figure shows an example of a ROC curve and its interpretation. 
Figure 2

Number of new loans before, during and after the crisis

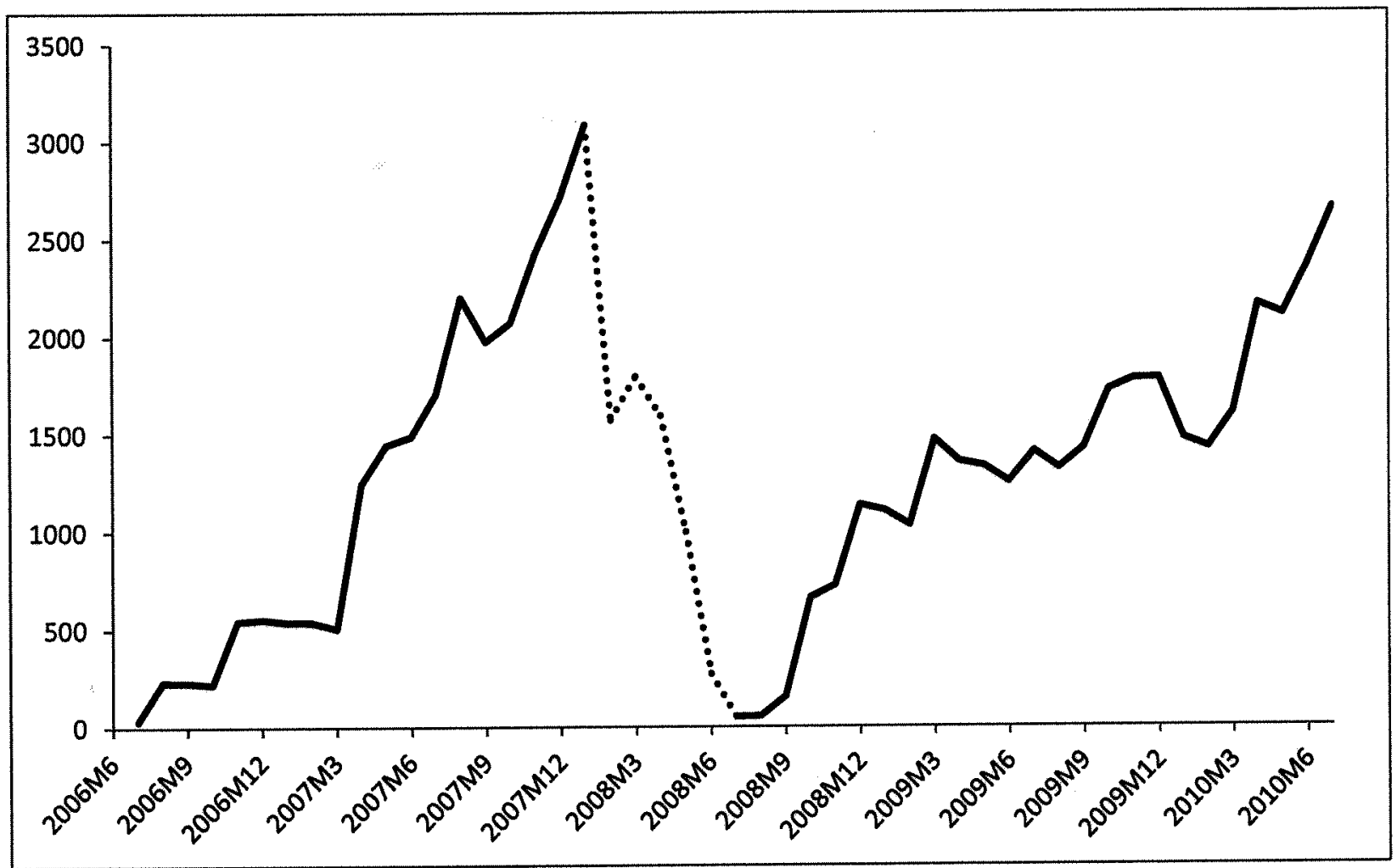

Note: This figure shows the number of new loans funded by our bank from 2006 to 2010 . The dotted part of the line indicates those months that we consider as our crisis period. 
Figure 3

ROC curves

Panel A: In-sample ROC curves

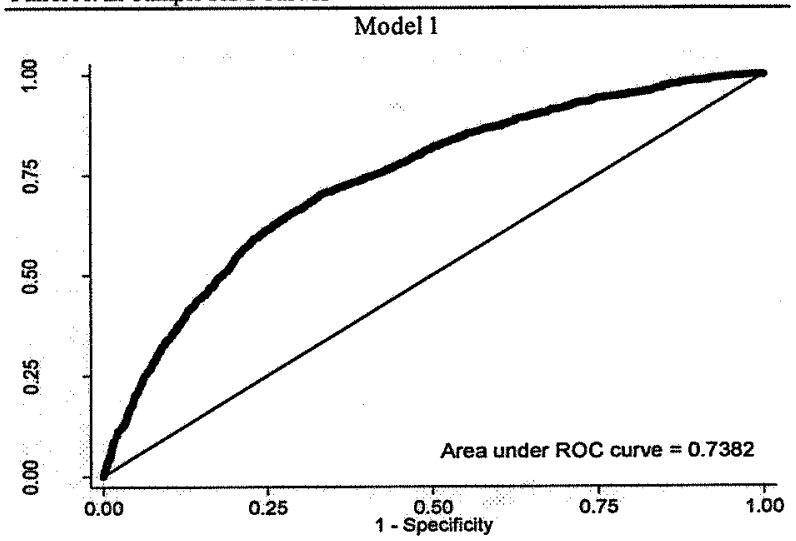

Panel B: Out-of-sample ROC curves
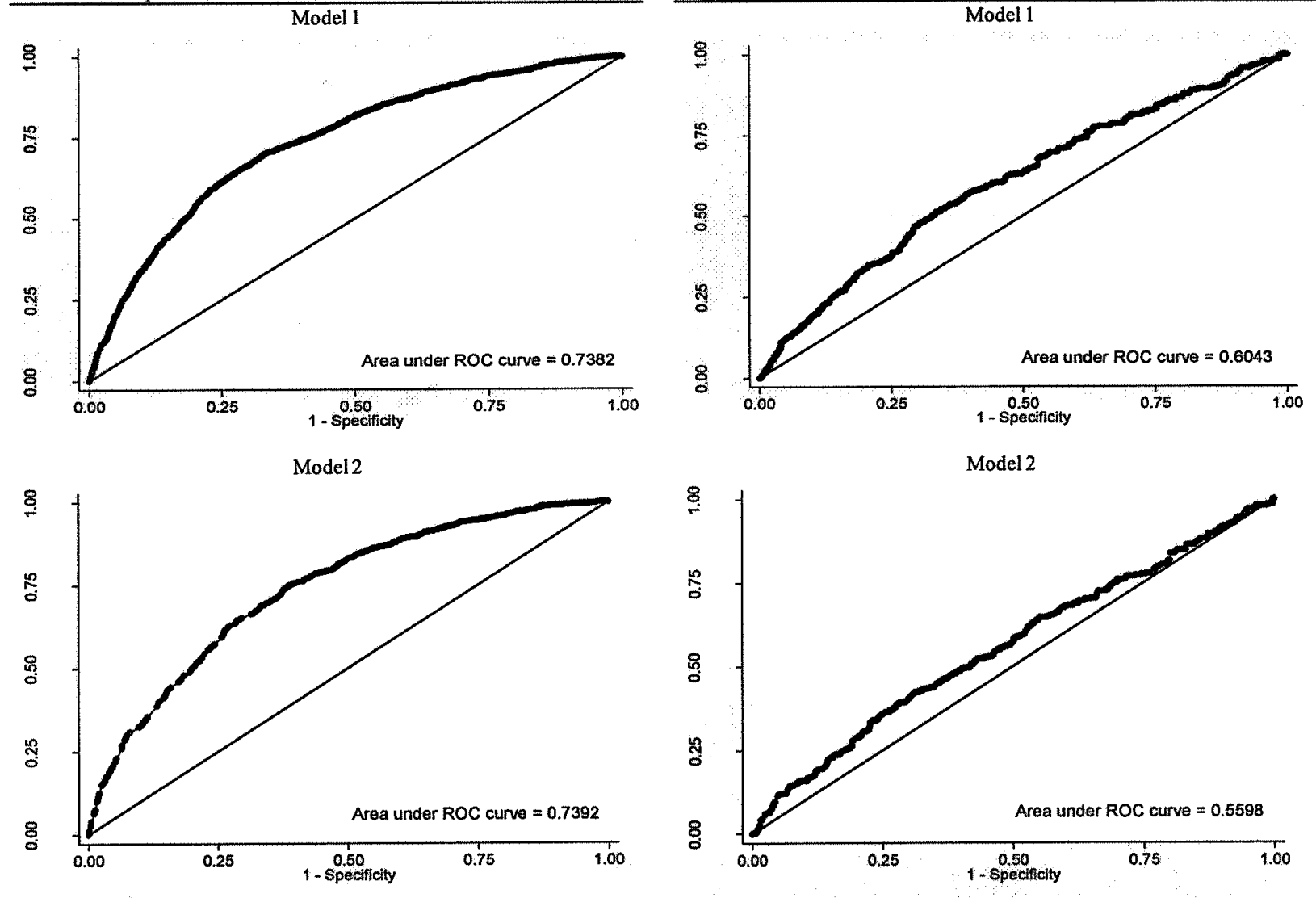

Model 2
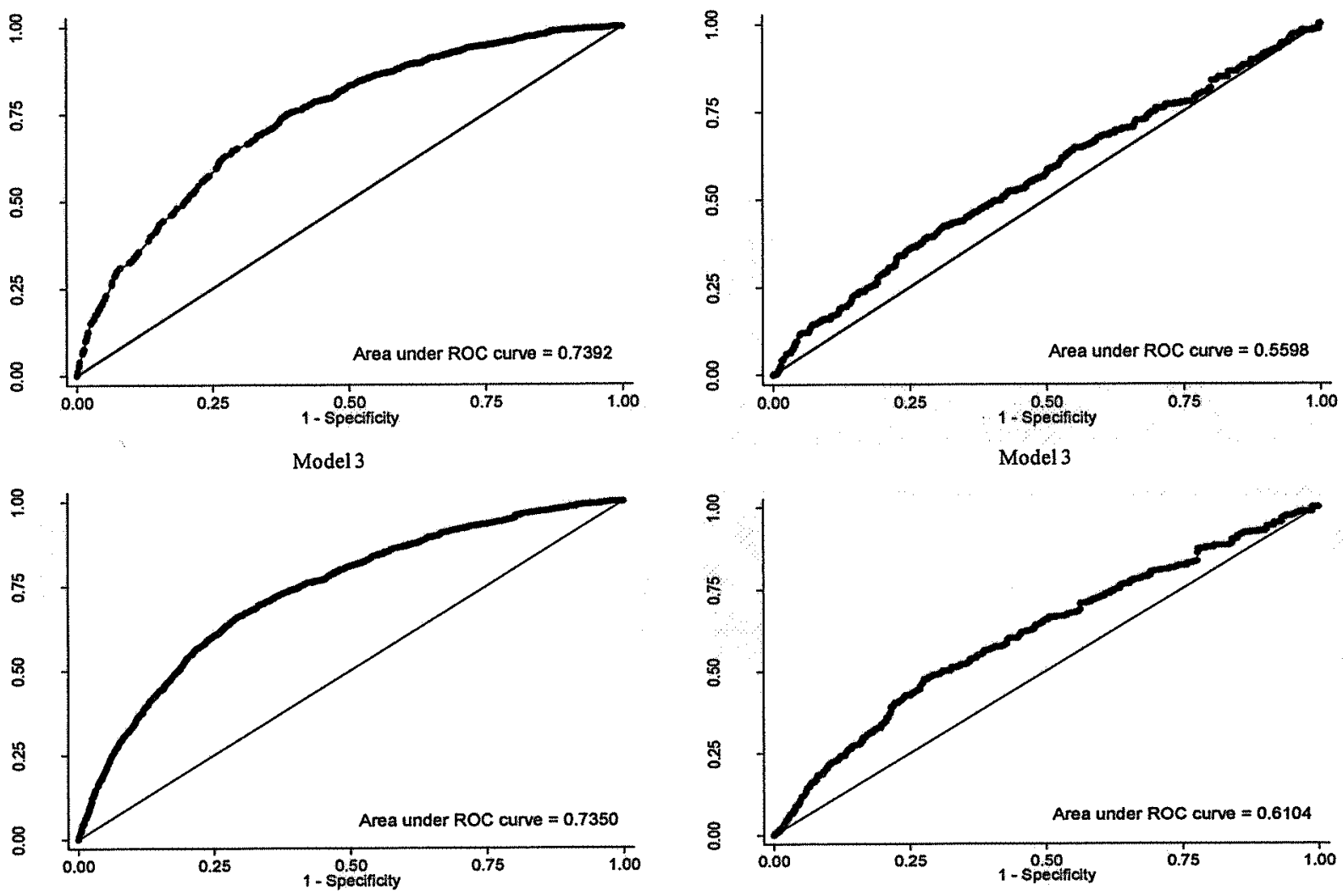

Model 4
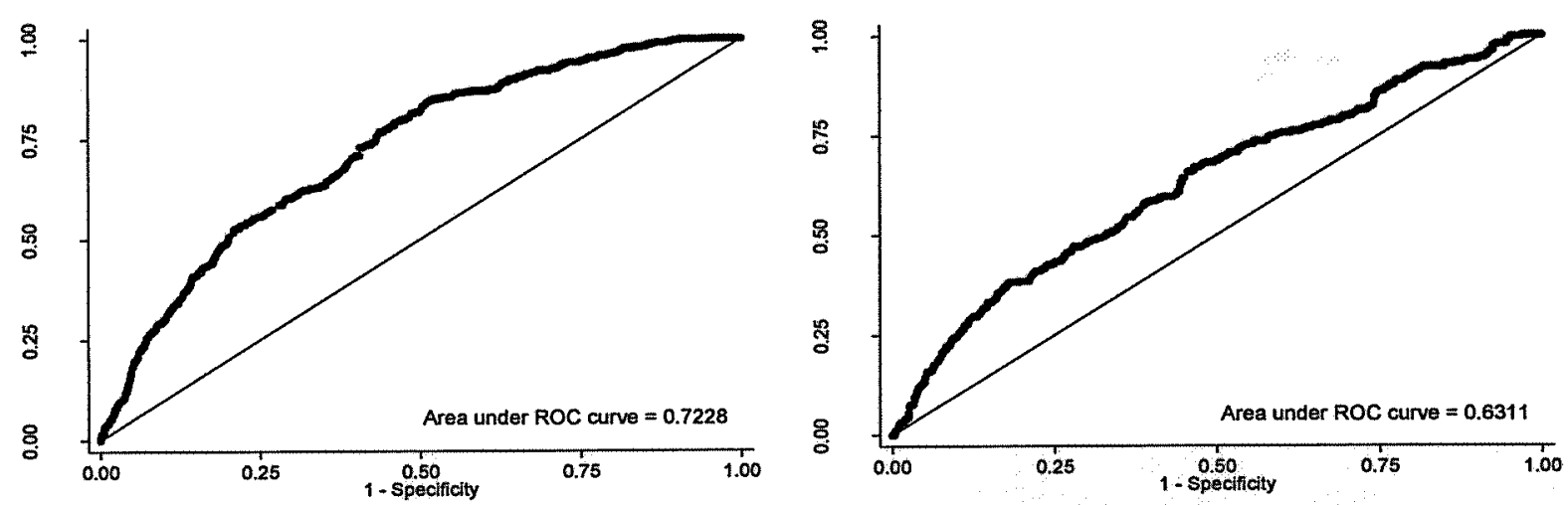

Note: The figure presents ROC curves of the four different CSMs both in and out of sample. A more concave curve (larger area under ROC curve) indicates a better predictive power of the CSM. 
Figure 4

Change in profit of model 3 and 4 with different cut-off values

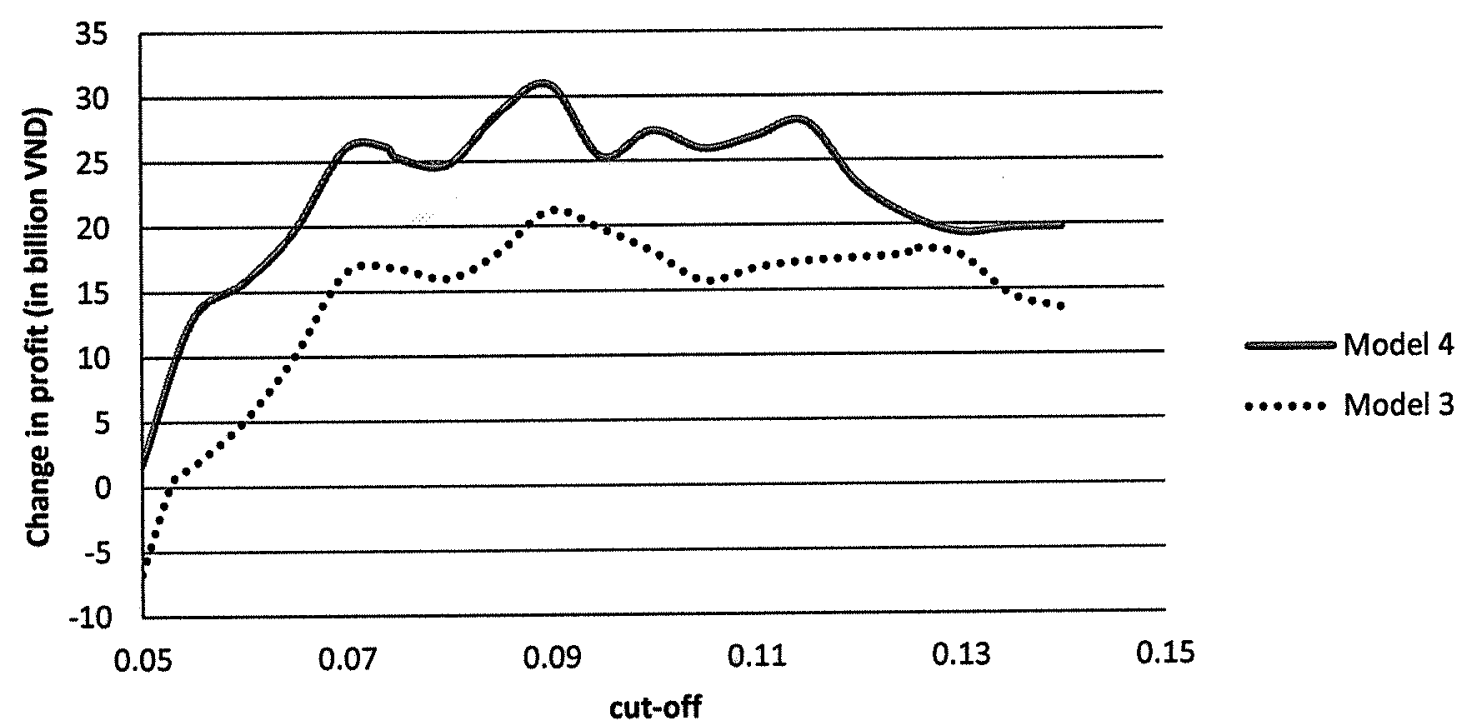

Note: This figure presents the change in profit when different cut-off points are applied to model 3 and 4 assuming that borrowers with a PD higher (lower) than the cut-off point will be rejected (accepted). 
Appendix 1

Descriptive statistics of model 4

\begin{tabular}{|c|c|c|c|c|c|}
\hline \multirow{2}{*}{$\begin{array}{l}\text { Variable } \\
\text { Age }\end{array}$} & \multicolumn{5}{|c|}{ Categories and default frequency of model 4} \\
\hline & 18 to 35 & 36 to 49 & more than 50 & & missing \\
\hline & $3.63 \%$ & $2.30 \%$ & $1.69 \%$ & & $2.94 \%$ \\
\hline \multirow[t]{2}{*}{ Gender } & male & female & & & \\
\hline & $2.99 \%$ & $2.12 \%$ & & & \\
\hline \multirow[t]{2}{*}{ Marital status } & married & single & widowed & divorced & \\
\hline & $2.27 \%$ & $4.35 \%$ & $1.74 \%$ & $5.09 \%$ & \\
\hline \multirow[t]{2}{*}{ Education } & $\begin{array}{l}\text { university } \\
\text { graduate, post } \\
\text { graduate }\end{array}$ & $\begin{array}{l}\text { college, high } \\
\text { school graduate }\end{array}$ & other & & missing \\
\hline & $3.13 \%$ & $2.50 \%$ & $2.05 \%$ & & $1.82 \%$ \\
\hline \multirow[t]{2}{*}{ Resident status } & house owner & tenant & $\begin{array}{l}\text { living with parents } \\
\& \text { other }\end{array}$ & & missing \\
\hline & $1.96 \%$ & $3.73 \%$ & $4.70 \%$ & & $6.40 \%$ \\
\hline \multirow{2}{*}{$\begin{array}{l}\text { Time at present address (in } \\
\text { years) }\end{array}$} & up to 5 & 6 to 16 & more than 17 & & missing \\
\hline & $2.57 \%$ & $1.99 \%$ & $3.80 \%$ & & $12.50 \%$ \\
\hline \multirow{2}{*}{$\begin{array}{l}\text { Monthly Income (in } \\
\text { million VND) }\end{array}$} & up to 10 & 10 to 30 & more than 30 & & missing \\
\hline & $3.20 \%$ & $2.42 \%$ & $2.61 \%$ & & $2.78 \%$ \\
\hline \multirow[t]{2}{*}{ Occupation } & management & labor work & retired, unemployed & other & missing \\
\hline & $3.30 \%$ & $4.94 \%$ & $1.67 \%$ & $2.47 \%$ & $2.65 \%$ \\
\hline \multirow{2}{*}{$\begin{array}{l}\text { Time with present employer } \\
\text { (in years) }\end{array}$} & 0 & 1 to 2 & 3 to 9 & more than 10 & missing \\
\hline & $2.28 \%$ & $4.62 \%$ & $3.05 \%$ & $1.28 \%$ & $5.38 \%$ \\
\hline \multirow[t]{2}{*}{ Loan purpose } & commercial & consumer & real estate & other & \\
\hline & $1.90 \%$ & $3.33 \%$ & $2.54 \%$ & $2.71 \%$ & \\
\hline \multirow[t]{2}{*}{ Loan duration (in months) } & up to 6 & 7 to 12 & 13 to 120 & more than 121 & \\
\hline & $0.00 \%$ & $1.17 \%$ & $3.11 \%$ & $2.28 \%$ & \\
\hline \multirow[t]{2}{*}{ Collateral to loan ratio } & 0 & more than 0 up to 1 & $\begin{array}{l}\text { more than } 1 \text { up to } \\
1.5\end{array}$ & more than 1.5 up to 5 & more than 5 \\
\hline & $3.85 \%$ & $5.20 \%$ & $2.84 \%$ & $2.33 \%$ & $1.76 \%$ \\
\hline \multirow[t]{2}{*}{ Time with bank (in years) } & 0 & 1 to 5 & more than 6 & & \\
\hline & $3.90 \%$ & $2.41 \%$ & $1.07 \%$ & & \\
\hline \multirow[t]{2}{*}{ Number of prior loans } & 0 to 1 & 2 to 7 & 8 to 19 & more than 20 & \\
\hline & $4.46 \%$ & $2.47 \%$ & $1.57 \%$ & 1.8396 & \\
\hline \multirow[t]{2}{*}{ Number of current accounts } & 0 to 2 & 3 to 4 & 5 to 84 & more than 85 & \\
\hline & $2.95 \%$ & $1.91 \%$ & $2.88 \%$ & $0.00 \%$ & \\
\hline \multirow[t]{2}{*}{ Number of saving accounts } & 0 & 1 to 12 & more than 13 & & \\
\hline & $3.35 \%$ & $1.62 \%$ & $1.06 \%$ & & \\
\hline \multirow[t]{2}{*}{ Region } & $\begin{array}{l}\text { central highland, } \\
\text { south central coast }\end{array}$ & south east & Red river delta & $\begin{array}{l}\text { Mekong delta river, } \\
\text { north central coast, } \\
\text { north east }\end{array}$ & \\
\hline & $1.66 \%$ & $2.47 \%$ & $3.57 \%$ & $6.10 \%$ & \\
\hline
\end{tabular}

